\title{
East Texas Archeological Society, Tyler, Texas, 1956-1959
}

\section{Mark Walters}

Heritage Research Center, Stephen F. Austin State University

Follow this and additional works at: https://scholarworks.sfasu.edu/ita

Part of the American Material Culture Commons, Archaeological Anthropology Commons, Environmental Studies Commons, Other American Studies Commons, Other Arts and Humanities Commons, Other History of Art, Architecture, and Archaeology Commons, and the United States History Commons

Tell us how this article helped you.

This Article is brought to you for free and open access by the Center for Regional Heritage Research at SFA ScholarWorks. It has been accepted for inclusion in Index of Texas Archaeology: Open Access Gray Literature from the Lone Star State by an authorized editor of SFA ScholarWorks. For more information, please contact cdsscholarworks@sfasu.edu. 


\section{East Texas Archeological Society, Tyler, Texas, 1956-1959}

Creative Commons License

(c) (i) (8)

This work is licensed under a Creative Commons Attribution-NonCommercial 4.0 International License 


\title{
East Texas Archeological Society, Tyler, Texas, 1956-1959
}

\author{
Mark Walters
}

\section{INTRODUCTION}

The East Texas Archeological Society (ETAS) was formed in Tyler, Texas, on June 26, 1956. The last record of any activity by that society was in 1959. This article is an attempt to document the brief history of that organization and identify some of the key players associated with it (Appendix 1-20 are supporting documents). One of those that played a major role was my late uncle, Sam Whiteside (Walters 2004). His family graciously gave permission to study his notes and records, which included the records from the ETAS. Unfortunately, Mr. Whiteside suffered from a debilitating disease that became acute in the summer of 1959, requiring hospitalization, and rendered him incapable of any further productive activity. His notes are not complete, but I will present what information is available. As a teenager, I belonged to the ETAS and attended the 1958 Texas Archeological Society (TAS) annual meeting in Tyler, Texas; the TAS annual meeting was not held in Tyler again until 2012 (Walters 2012). I was fortunate that Mr. Whiteside included me on some of his visits to area salvage projects that were being conducted in East Texas during this period. His son Jim Whiteside and I also helped him on several of his projects on Caddo sites in East Texas. He inspired me to continue that interest until the present.

\section{EAST TEXAS ARCHEOLOGICAL SOCIETY 1956}

\section{Formation}

Everett Taylor, Jr., Managing Editor of the Courier-Times-Telegraph, Tyler, Texas, (VOL. 79, NO. 249), in his column Huntin' ' $n$ Peckin' posted an announcement of a meeting slated for June 26, 1956, "for those who like to dig into the past (literally or figuratively)" for the purpose of forming the East Texas Archeological Society (ETAS) in Tyler, Texas (Figure 1). The announcement was made by Antonio A. (Tony) Andretta, who explained that "the society is being formed by amateurs, for amateurs with like interests." In a mail-out (Figure 2) addressed to "fellow collectors," Mr. Andretta stated that the formation of the ETAS is long overdue. He stated that the "purpose of the society will be to encourage the study of archeology in East Texas and adjacent regions; the proper collection, preservation and interpretation of artifacts and other remains of the native tribes of this region and the creation and publication of researches relating to this." Mr. Andretta further stated that: "Arrangements have been made for the local society to join the Texas Archeological Society, affording professional help and research facilities, as well as guidance and assistance from noted people in the field of Archeology." Those attending are encouraged to bring their "choice artifacts so that all may admire."

Responding by letter to the announcement were R. L. (Bob) Turner of Pittsburg (Figure 3), who stated that he would be in attendance and was bringing Messrs Wilson of Hughes Springs, German of Lone Star, and Nicholas of Daingerfield. Also responding to the invitation was D. T. Loyd, Vice President of the First National Bank of Gilmer, Texas, who added that he thought he had "one of the best Indian artifact collections in East Texas" (Figure 4). 


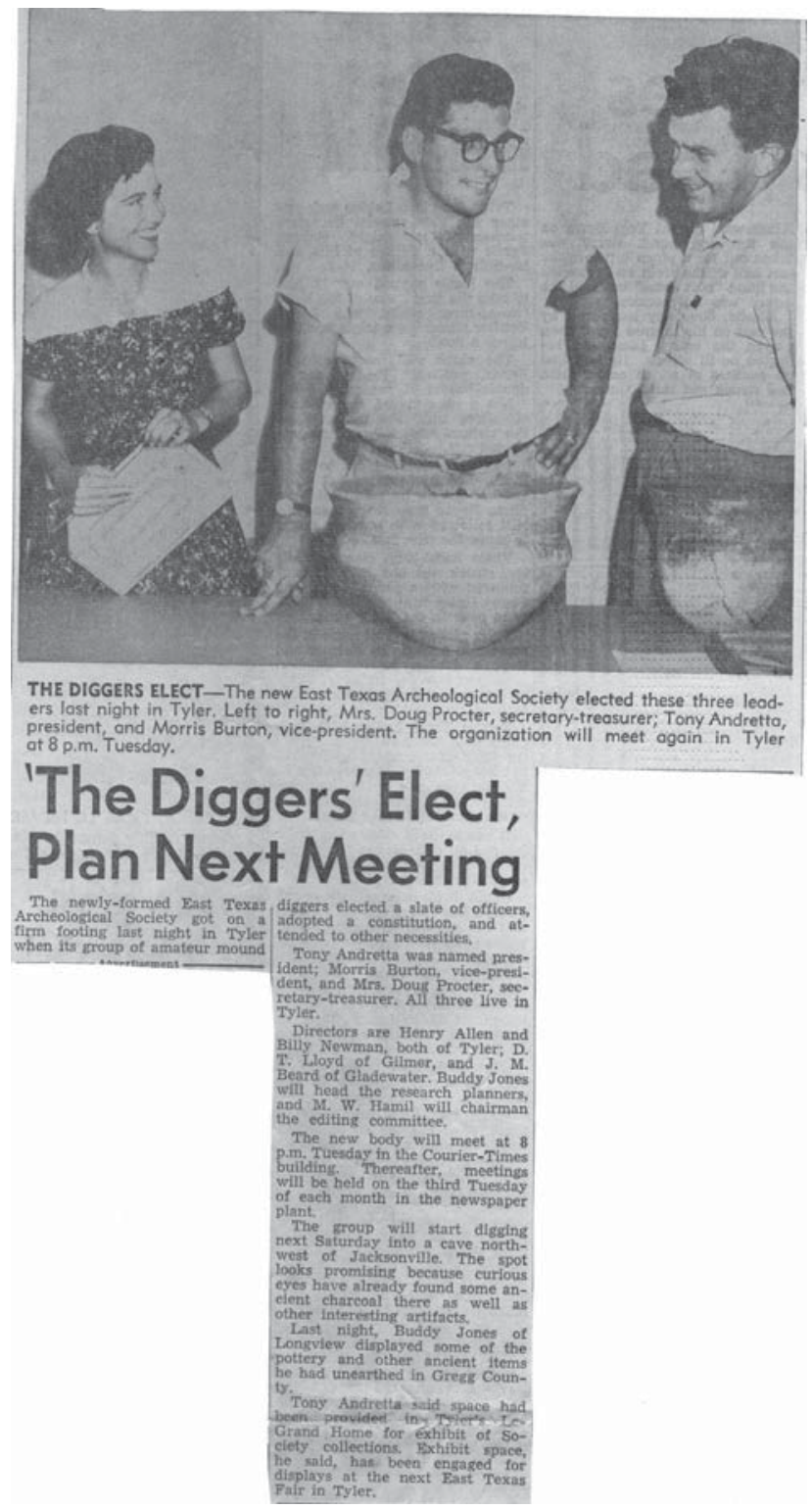

Figure 1. June 15, 1956 announcement in the Tyler Courier-Times-Telegraph.

The Wednesday evening, June 27, 1956, addition of The Tyler Courier-Times posted an article announcing "a group of curiosity-ridden East Texans gathered in the Courier-Times last night and set up an organization [ETAS] that will make mound diggers of the group" (Figure 5). Mr. Andretta of Tyler was chairman and named a committee consisting of Morris Burton, Tyler, chairman, D.T. Loyd of Gilmer, and Dr. Oren Murphy of Tyler to prepare a constitution and by-laws for submission to a July 10 session at which officers are to be elected.

Fifty-five East Texans were enrolled as charter members. The ETAS was to be affiliated with the Texas Archeological Society (TAS), which had close ties with the University of Texas and its museum.

Chairman Andretta informed the group that "the new society had permission to explore into 21 mounds and two ancient burial places not far from Tyler. The mounds are in a large circle, with an upthrust in the center." 


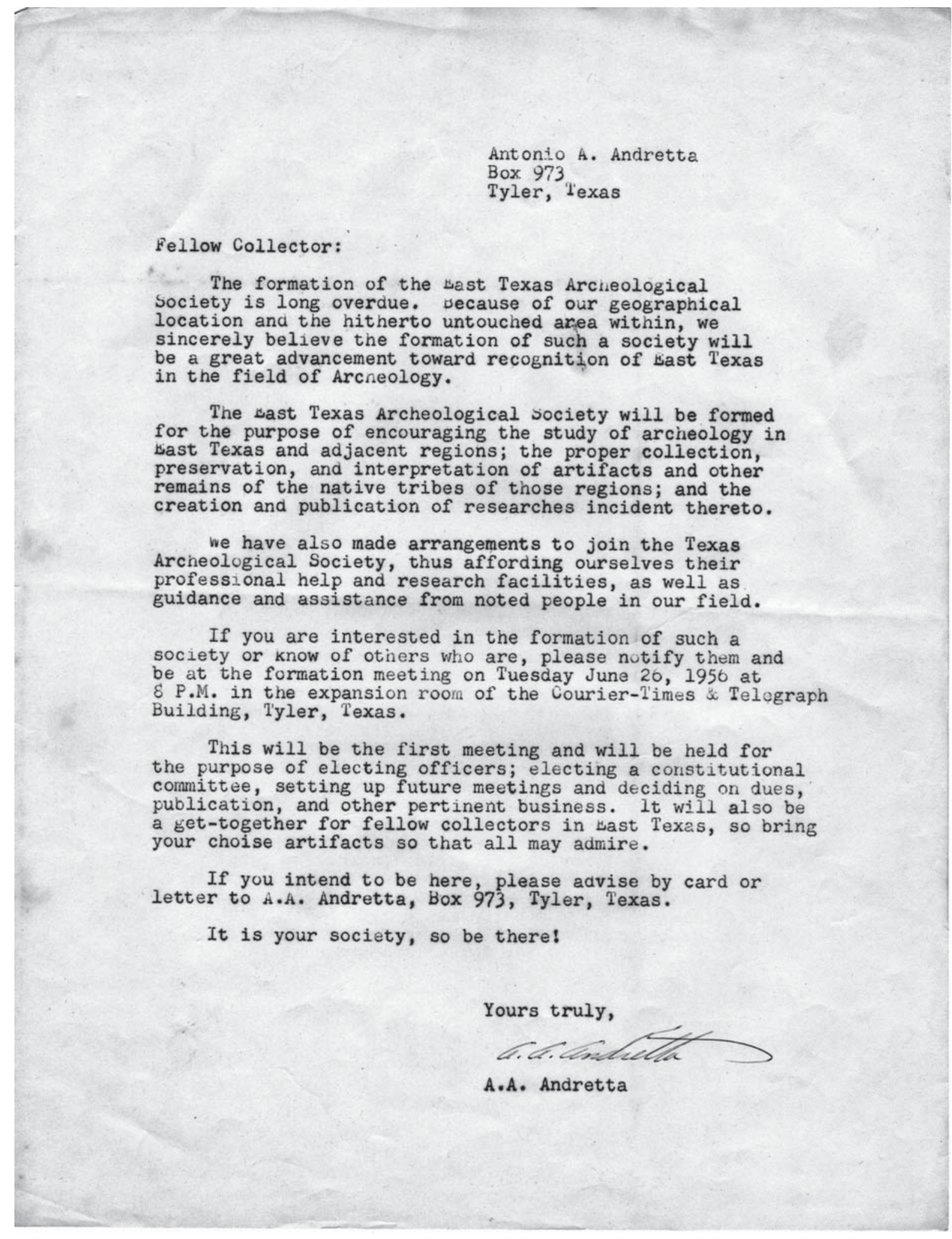

Figure 2. Mail-out announcement for the ETAS. 

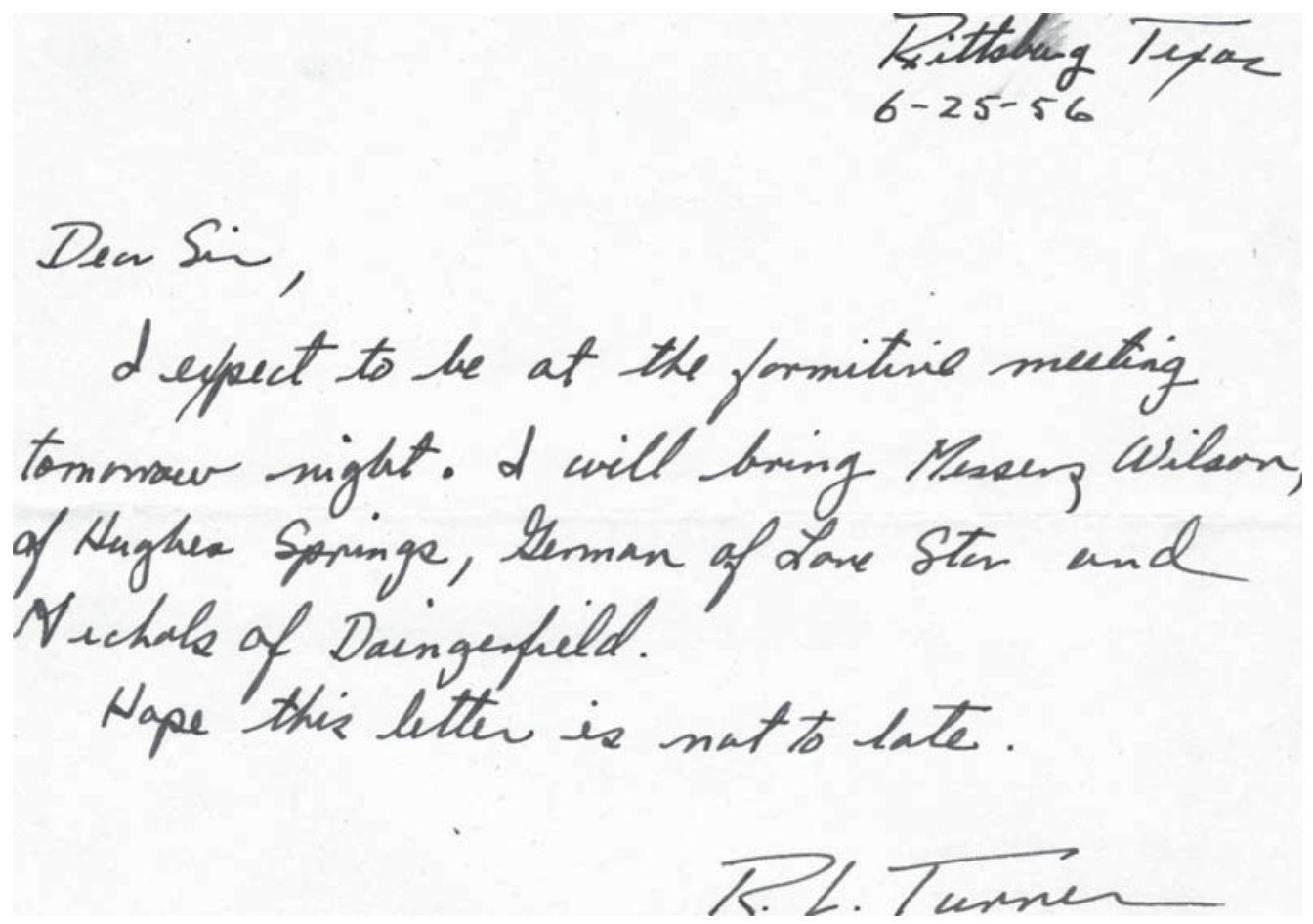

Figure 3. June 25, 1956 reply to mail-out from Robert Turner.

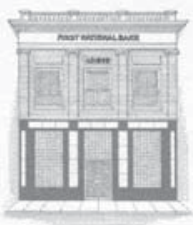

(4)

\section{FIRST NATIONAL BANK}

GILMER.TEXAS

D. T. LOVD

June 21,1956

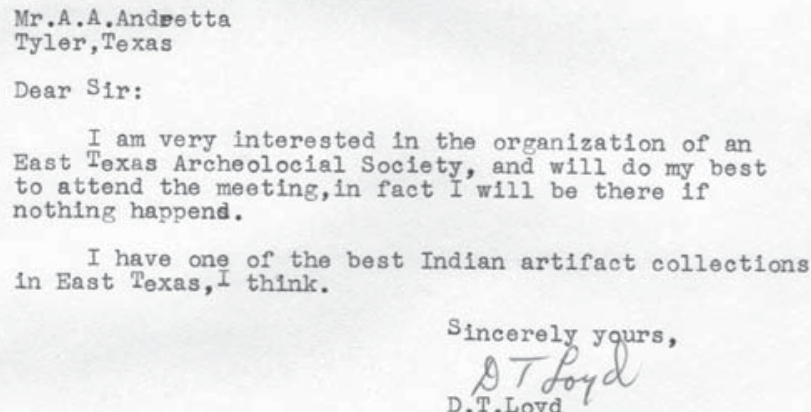

Figure 4. June 21, 1956 reply to mail-out from D. T. Loyd. 


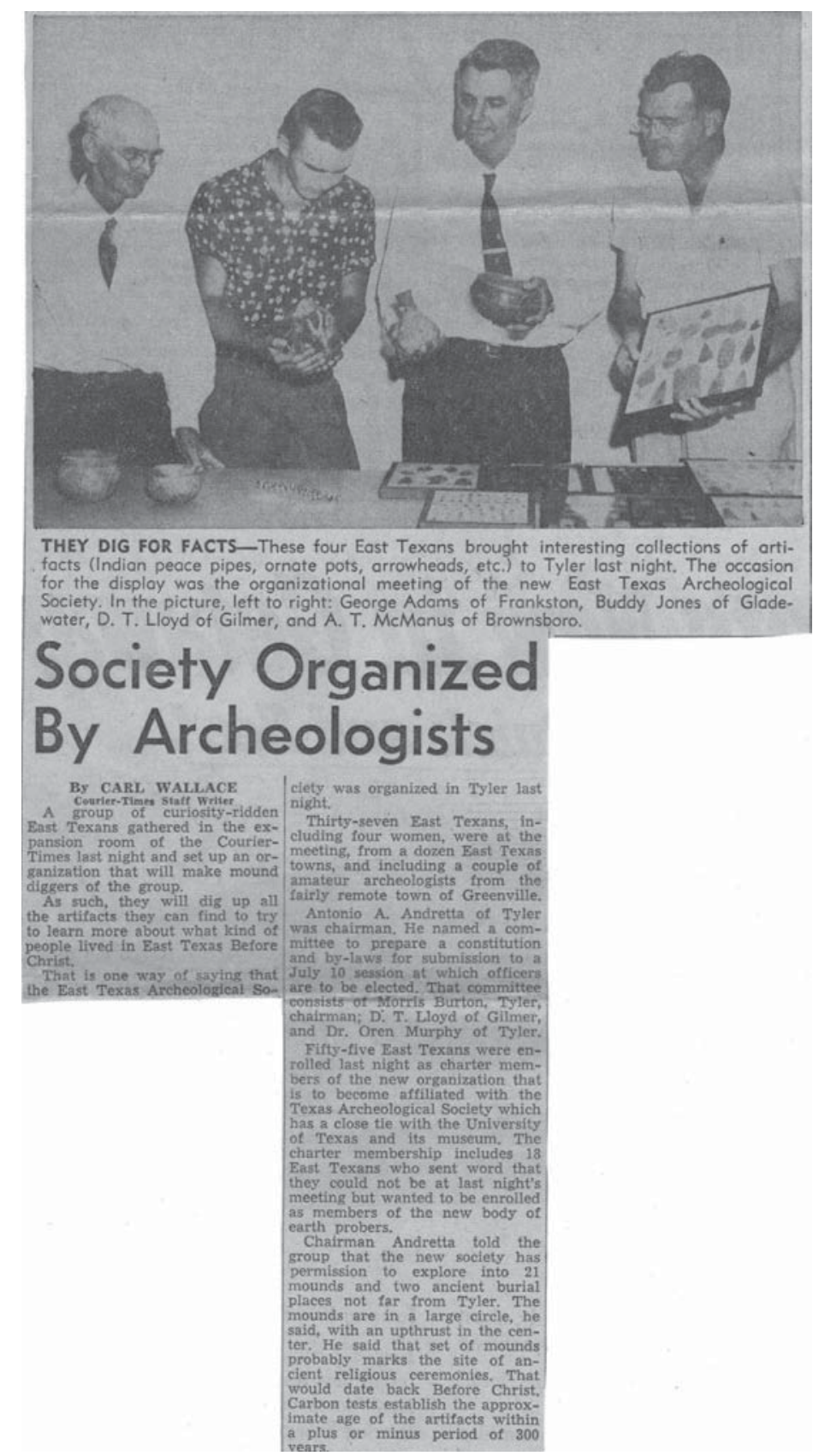

Figure 5. June 27, 1956 announcement in Tyler Courier-Times.

The Dallas Morning News, on July 5, 1956, had an article by Sam Acheson entitled "Unearthing East Texas' Past," in which it was reported "that a group of "curiosity-ridden" East Texans had formed an archeological society. They "are carrying on the fine zeal displayed by the pioneer in unearthing the secret past of East Texas, the late James E. Pearce of Austin." "Professor Pearce, long-time head of the anthropology department of the University of Texas, was especially excited by what he found there (east Texas). In the Indian mounds located in almost all parts of the area, he gathered evidence that enabled him as a master detective to piece together a vivid picture of the original Tejas Indians" (Figure 6). 


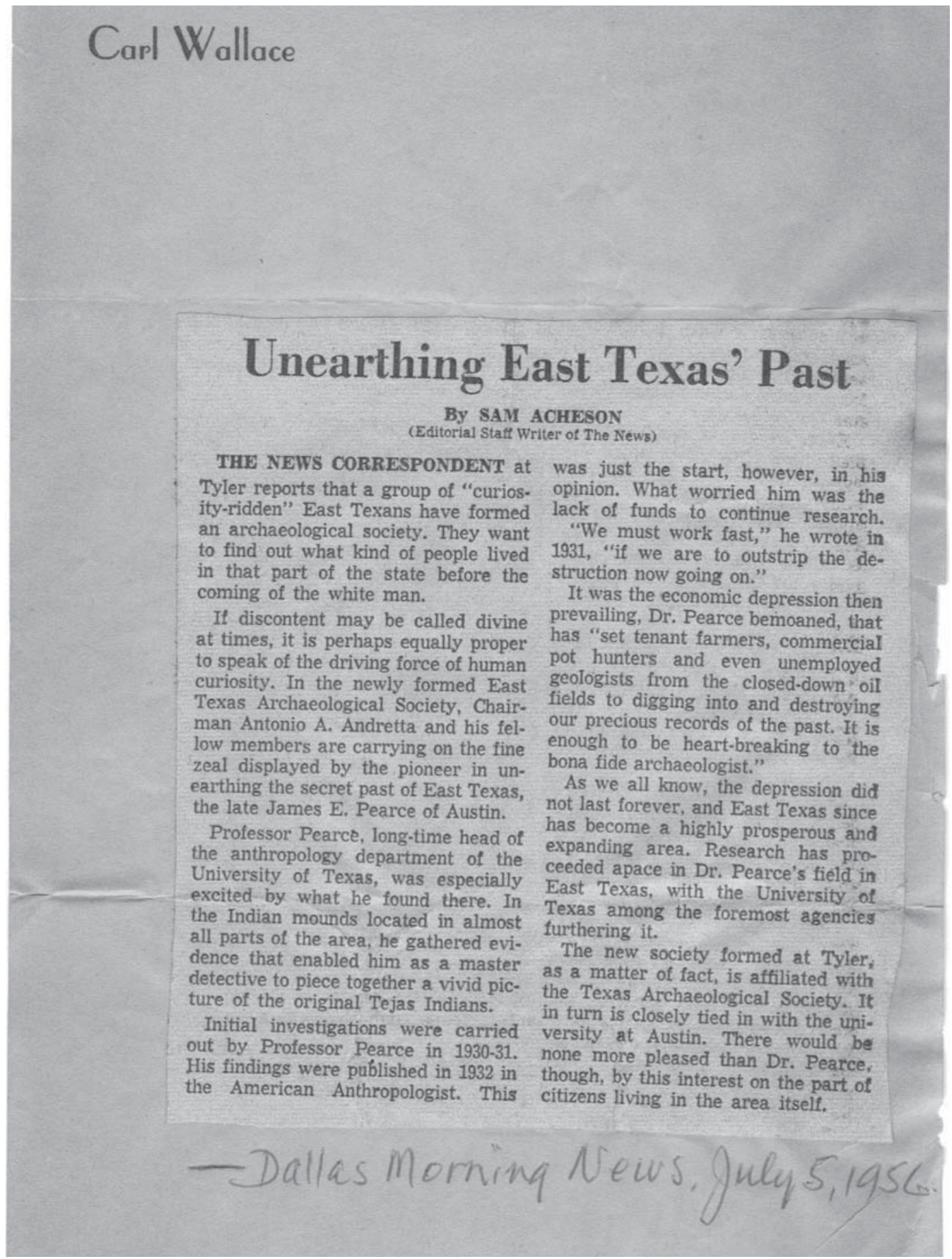

Figure 6. July, 51956 announcement in the Dallas Morning News.

\section{HISTORY}

\section{July 10, 1956 Meeting}

The July 10, 1956 meeting was called to order by Mr. Andretta, who immediately turned the meeting over to Morris Burton, nominating chairman of the by-laws committee at the July 3 meeting. Mr. Burton presented an outline of the by-laws, which later included some changes. 
The officers of the ETAS were then elected:

President: Antonio Andretta

Vice President: Morris Burton

Secretary-Treasurer: Jeanelle Proctor

Board of Directors:

D. T. Loyd

Henry Allen

J. M. Beard

W. R. (Billy) Newman

Field Chairman \& Director of Research: Buddy Jones

Assistants: Derrell Sanders, Earl Guy, and Ray Vanderpool

It was decided that the regular meetings would be held once a month, on the third Tuesday of the month at 8 p.m. in the Courier-Times Building. Members would receive notification or reminders of the meetings. The meeting was then turned over to Buddy Jones, who gave a talk and displayed some of the pottery and other ancient items he had unearthed in Gregg County, Texas. Andretta adjourned the meeting. Membership dues were collected.

Buddy Calvin Jones, born October 31, 1938, was 17 years of age when he was appointed Field Chairman \& Director of Research by the East Texas Archeological Society. He was one of the charter members of the society that met in Tyler, Texas. He had a long and varied career as an amateur and later professional archaeologist. His vast collection is now housed at the Gregg County Historical Museum in Longview, Texas (Perttula et al. 2006).

The newly formed ETAS began making plans for future activities. They issued membership cards (Figure 7) and created a site survey form (Figure 8) to standardize investigations. They also created a Site Release Form (Figure 9) to be signed by landowners granting society members surface and sub-surface excavation rights. For the purposes of defining East Texas, a map was drawn "defining an area extending east of a line drawn north through Waco, Texas, and north of a line drawn east through the same city, extending to the northern and eastern boundaries of the State of Texas." A side-note attached to the map states "Let's get a map of the Central Texas Society and keep out of their territory, if possible."

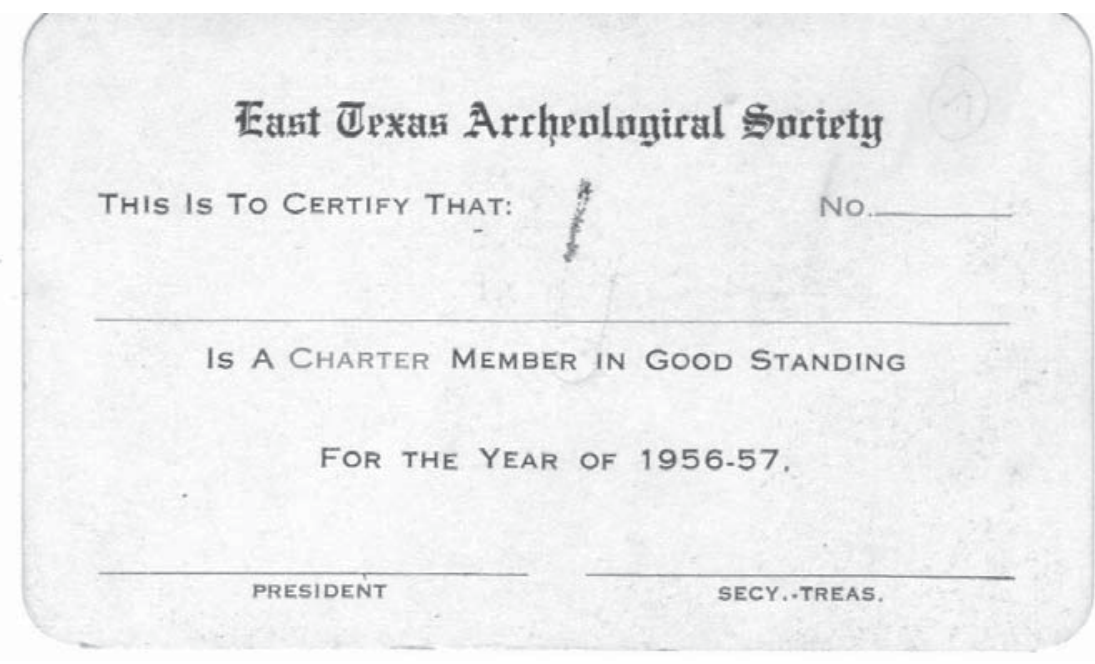

Figure 7. ETAS membership card. 
Site No

EAST TEXAS ARCHEOLOGICAL SOCIETY: SITE SURVEY CAS No...-...

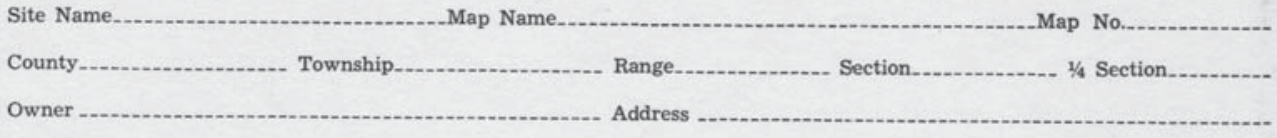

Location: Starting from

travel N E S W along road (RR)

miles. Site on N E S W side;

distant from road

Valley, Flat, Plateau, Hill: top, slope, foot, facing

Nearest water: Distance.

; side

Surroundings: Protection from N E S W. View to N E S W. Other

Nature of Site: Campsite, blowout, rock shelter, workshop, quarry, burial, etc.

With tipi rings, fireplaces, walls, pits, bones. Area of site

Artifacts: pictographs, pottery, stone points, metates, manos, beads, etc.

Your collections from site:

Others

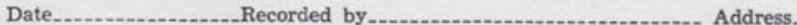

Notebook

(On back or on extra card, give additional data, plans, drawings, photos, sketch map, etc.)

Figure 8. ETAS site survey card.

\section{EAST TEXAS ARCHEOLOGICAL SOCIETY}

SITE RELEASE FORM

For

SURFACE \& SUB-SURFACE EXCAVATION RIGHTS

TO WHOM IT MAY CONCERN,

Land Owner's Name:

Location:

Address: —County __ Texas

This is to state that $\mathrm{I}$

permission to the East Texas Archeological Society to survey and explore my land for the express purpose of ascertaining if Indian sites are present on my land.

I also grant permission if said Indian occupation signs are present to the East Texas Archeological Society to excavate.

I am also to understand that all Indian artifacts removed from my land will be the property of the East Texas Archeological Society, I thus grant surface and sub-surface exploration rights to the East Texas Archeological Society.

I am also to understand that any damage done to my property will be the responsibility of the East Texas Archeological Society who will rectify any claim valid against it.

I am also to understand that only authorized members of the Society will be allowed to participate in excavation, survey, surface collecting, and exploration. Each authorized member will have on their person an authorized card for the site containing the site name and number signed by the Society president and the land owner.

Signed this day of

in the month of

19

Owner:

For the East Texas Archeological Society: Office

WITNESSES:

Figure 9. ETAS site release form. 
'The Diggers' Elect, Plan Next Meeting was the title of a July 11, 1956 article in The Tyler CourierTimes (Figure 10). The article noted that the newly elected officers were: Tony Andretta as president; Morris Burton, vice-president; and Mrs. Doug Proctor, secretary-treasurer. Directors were: Henry Allen and W.R. (Billy) Newman, both of Tyler; D. T. Loyd of Gilmer, and J. M. Beard of Gladewater. Buddy Jones headed the research planning and M.W. Hamil chaired the editing committee.

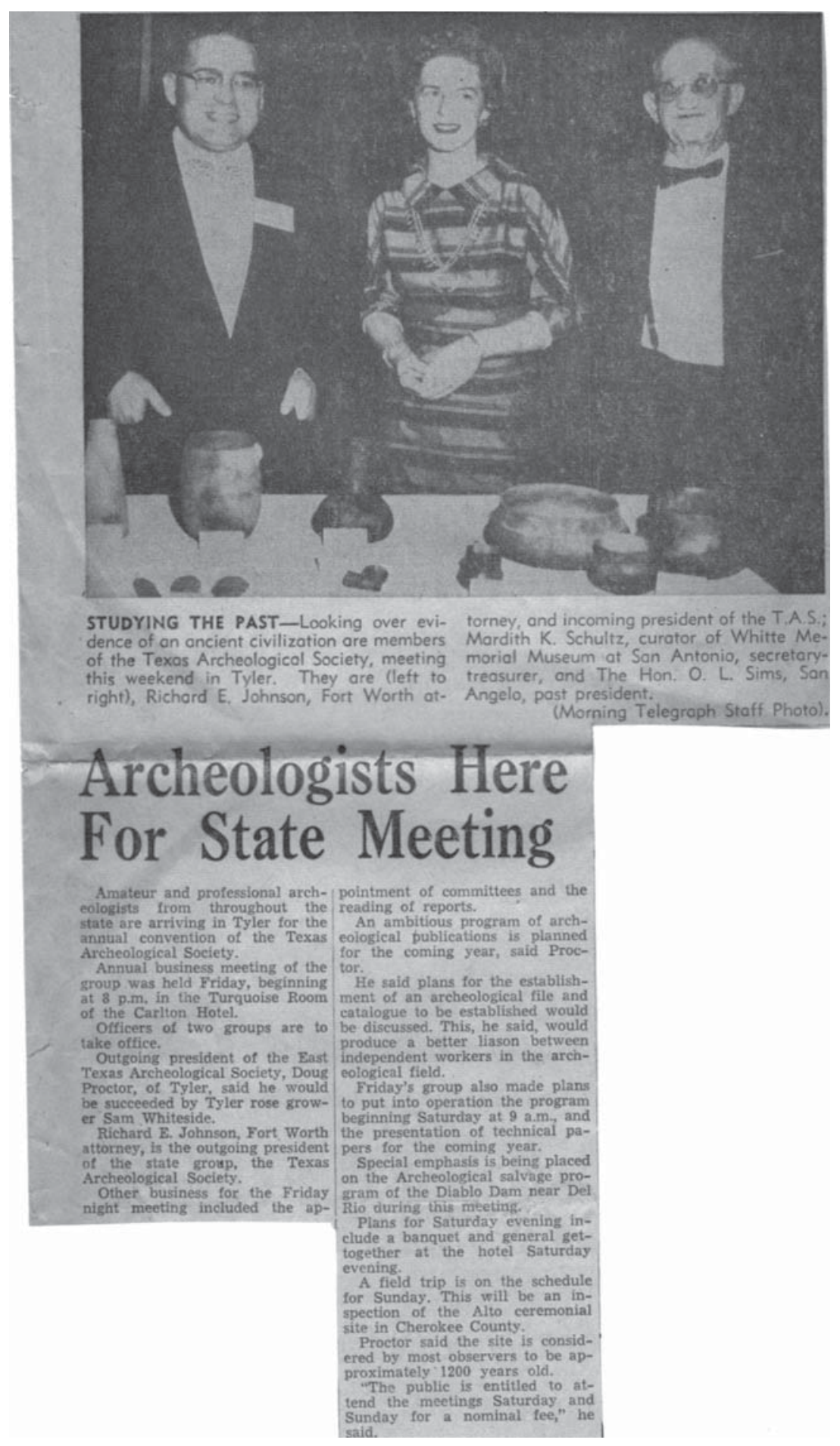

Figure 10. July 11, 1956 Tyler Courier-Times announcement for ETAS meeting. 
Tony Andretta said "space had been provided in Tyler's LeGrand Home for exhibit of Society collections. Exhibit space has been engaged for displays at the next East Texas Fair in Tyler."

The group made plans to start digging the next Saturday at a cave northwest of Jacksonville, Texas. According to the article "the spot looks promising because curious eyes have already found some ancient charcoal there as well as other interesting artifacts".

In a July 24, 1956 letter from Edward J. Jelks, Department of Anthropology, The University of Texas at Austin and also Acting Secretary-Treasurer of the Texas Archeological Society to Mr. Andretta, Mr. Jelks made reference to the Cary Lake Cave site by stating: "Your description of the cave site being excavated by the East Texas Society is extremely interesting. I gather that the deepest occupational level contains Plainview points, animal bones, human bones, and charcoal. If I understand the situation correctly it is surely quite an important site. I would suggest, therefore, that you make a special point of preserving at least half of the caves deposits until such a time as the site can be examined by at least one professional archeologist" (Figure 11).

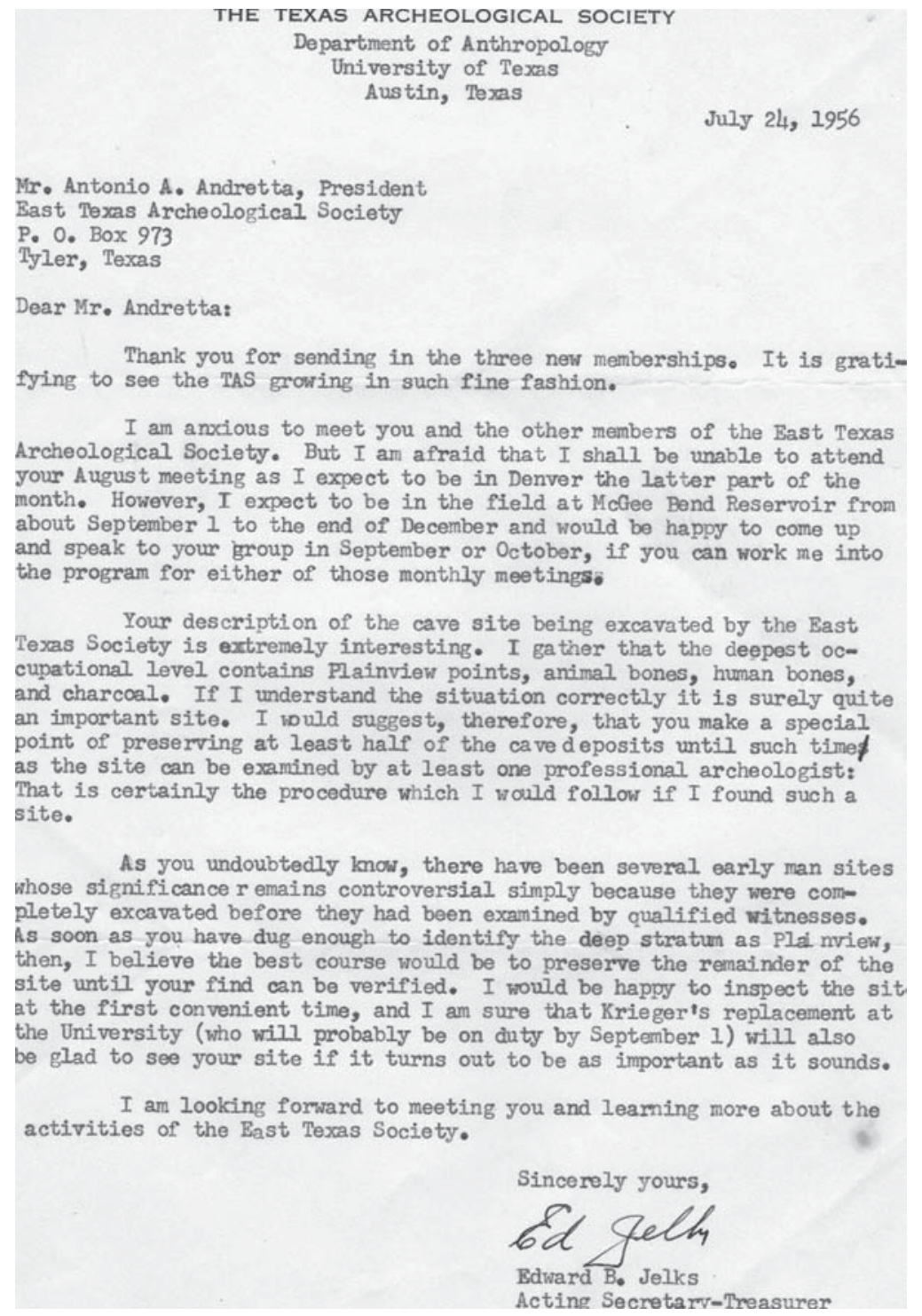

Figure 11. July 24, 1956 letter from Edward B. Jelks. 


\section{Executive Committee Meeting, August 14, 1956}

President of the ETAS Antonio Andretta called an Executive Committee meeting on August 14, 1956 (Figures 12a-b). As noted in the July 11, 1956 Special Meeting, the society had made plans to investigate the Cary Lake Cave site, located northwest of Jacksonville, Texas.

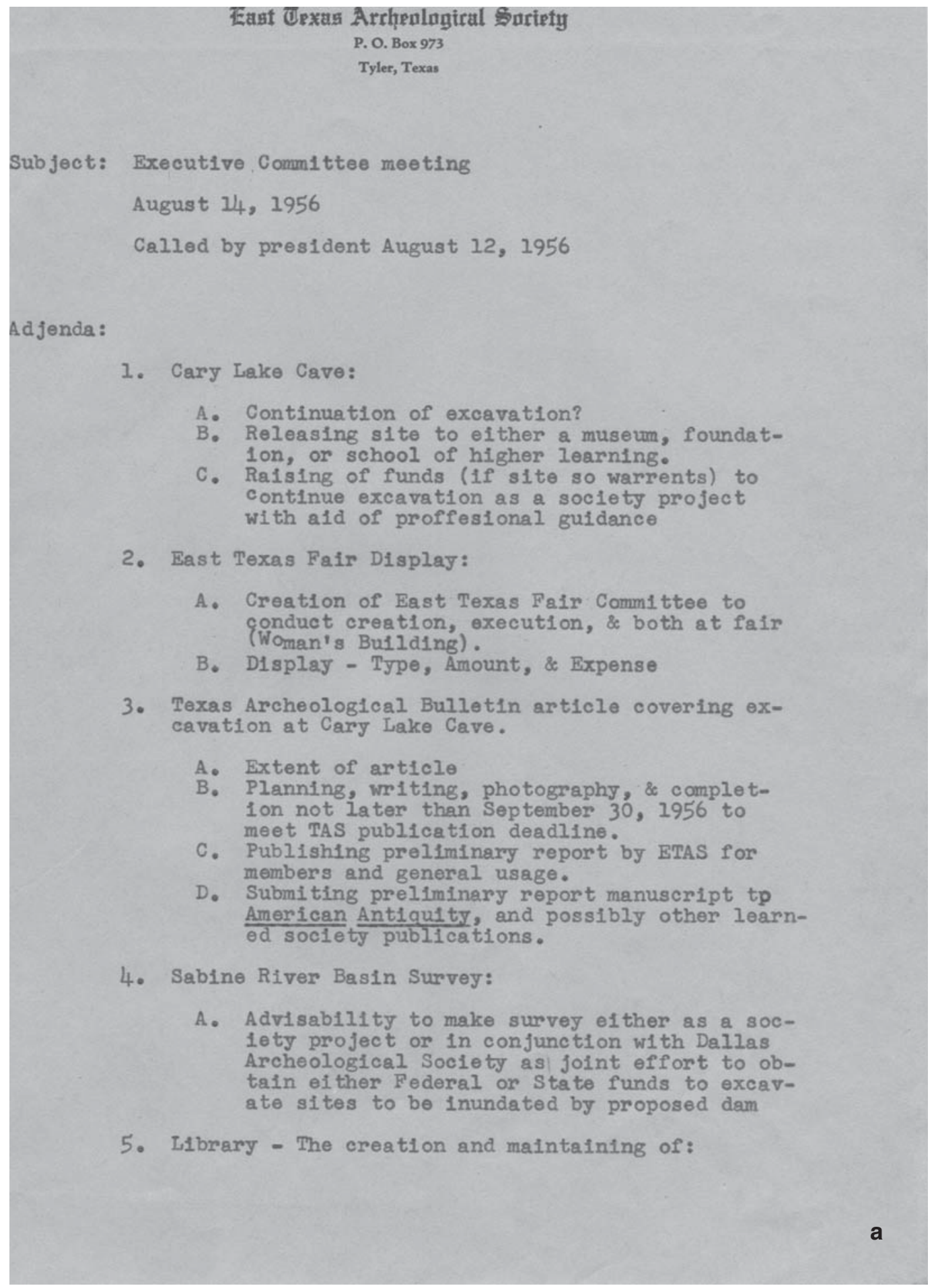

Figure 12. ETAS August 14, 1956 meeting agenda: a, p. 1; b, p. 2. 


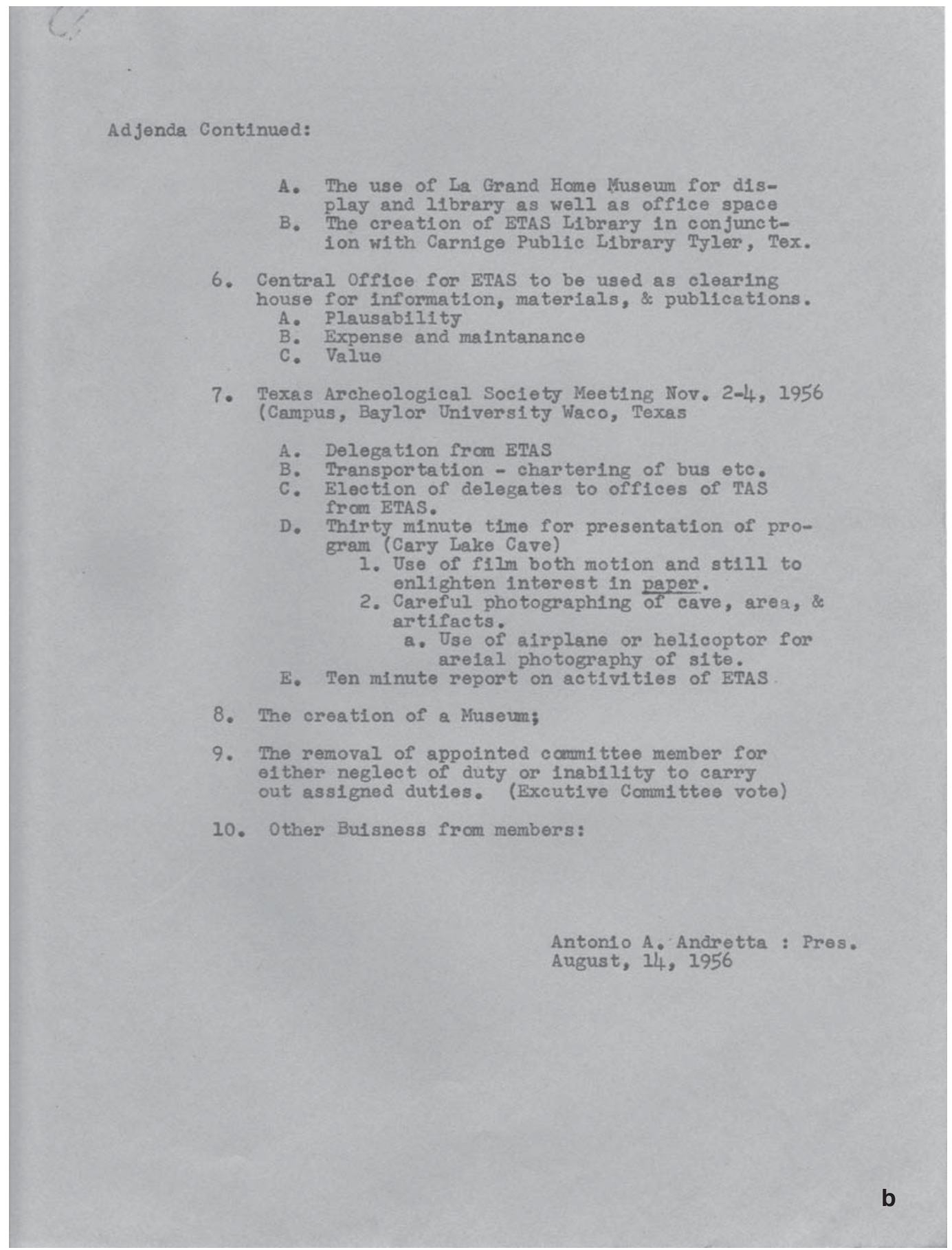

Figure 12. ETAS August 14, 1956 meeting agenda: a, p. 1; b, p. 2. 
The agenda for the August 14, 1956 meeting listed the Cary Lake Cave site as the first item of business. Evidently, problems concerning these investigations were causing friction within the society. There were serious allegations that a member of the society had "salted" the site with artifacts that were reportedly stolen from Texas Tech University in Lubbock, Texas. Concerning the Cary Lake Cave site, the August 14 meeting agenda listed three options open to the society: 1. Continuation of excavation?

2. Releasing the site to either a museum, foundation, or school of higher learning.

3. Raising funds (if site so warrants) to continue excavation as a society project with the aid of a professional.

In response to these options, a statement was issued by the Field Committee:

1. The method and control of the excavation of the cave shall be determined by the Field Committee.

2. Excavation of the cave shall be on weekends. Restrictions on the cave were only originated to en-

sure for the proper excavation of the cave. They were not originated to show the authority of one man of the committee. As a result we hope that no ill-will will occur among the members of the society.

The Chairman then stated that: 1 . The members of the committee shall have the authority to supervise the excavation of the cave during the absence of the chairman; 2 . They will carry on excavation as specified by the Field Chairman only; and 3. Any member of the society may have the rightful opportunity to excavate in the cave as long as he is under the supervision of one member of the committee. However, special permission to excavate without the supervision of a member of the Field Committee may be granted in extreme cases. It can only be granted through the Field Chairman. Field Committee members included: Henry Allen, Derrell Sanders, Don Dickson, Ray Dennis, Sam Whiteside, Phillip Whiteside (Sam Whiteside's brother), Ray Vanderpool, Earl Green, and Buddy Jones (Field Chairman).

The Field Committee adapted the following excavation rules for the Cary Lake Cave site:

Any member who fails to abide by these rules will be going against the purpose of the society, thus he should not have joined the society. 2 . Any member who fails to abide by these rules set up by the Field Committee, and accepted by the society, will have his membership voted on by the Board of Directors (provided by the Field Chairman as a written directive included in ETAS records).

Other Agenda items included: (a) East Texas Fair Display; (b) Texas Archeological Society (TAS) Bulletin article covering excavation at Cary Lake Cave (Plans were made to submit an article on the Cary Lake Cave excavation to TAS for publication); (c) Sabine River Basin Survey (To determine the plausibility of conducting survey work as a society project or in conjunction with the Dallas Archeological Society and obtaining Federal or State funds to excavate sites to be inundated by the proposed Blackburn Crossing Reservoir (present- day Lake Palestine); (d) Library (Setting up a library at the La Grand Home Museum and/or the Carnegie Public Library, Tyler, Texas); (e) Central office for ETAS (Plausibility of establishing a central office as a clearing house for information, materials, and publications); (f) Texas Archeological Society Meeting Nov. 2-4, 1956, Campus of Baylor University, Waco, Texas (Discussion concerning sending delegates from ETAS to TAS, chartering a bus, presenting a program to TAS on the Cary Lake Cave site, and reporting on activities of the newly formed ETAS); (g) the creation of a museum; (h) the removal of an appointed committee member for either neglect of duty or inability to carry out assigned duties (This item evidently is related to the previously discussed conflict that arose at the Cary Lake Cave site); and (i) other business from members. These items were submitted by President Antonio A. Andretta.

\section{September 20, 1956 Meeting of the ETAS}

The meeting was called to order by the president Antonio A. Andretta. He asked Mr. Doug E. Proctor to give a brief report of the TAS meeting which was scheduled for November 2-3, 1956 in Waco, Texas. 
Mr. Proctor's report makes a marked change of attitude of the ETAS toward the TAS. It is unclear what prompted this change but Mr. Proctor states: "from his viewpoint we (ETAS) could expect exactly nothing from the TAS. They (TAS) were willing to support our society (ETAS) only morally. His thought was that the TAS and the ETAS had only a common meeting ground to swap and find information. It was moved that our society (ETAS) keep in touch with the TAS for representation."

\section{ANNUAL MEETING OF THE TEXAS ARCHEOLOGICAL SOCIETY}

The 1956 TAS Annual Meeting was held at Baylor University, Waco, Texas, on November 2-3 (Figure 13). Several members of the ETAS attended and President Antonio A. Andretta was listed to present a paper on the Cary Lake Cave site.

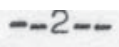

Papers to be Presented at the Regular Meeting

The following papers are to be presented. at the regular meeting. There will be opportunity for brief discussion after each paper. The schedule is crowded (assign of the active interest of our members), and the President will heve to hold each speaker strictly to his time linit.

1. The changing geological and climatic evniroments under which ixerd prehistnric man. Frank Bryan.

2. The Cahinnio-Caddo; a contact unit in the eastern margin of the Caddo area. Mrs. Thomas L. Hocges.

3. Archeology begins in the province of Alberta, Canada. E. Mott Davis

4. The Carey Lake Cave Site. A. A. Andretta

5. Artifacts from Dimit County, Texas. Claud Bramblett

5. Pendants, plows, plates and pottery. Otto 0. Watts

7. The Levisville site and carbon-14 dates of 37,000 years. W. W. Crook, Jr., and R. K. Harris

8. The Eenesis of the Burnt Rock Midden Culture. Frank E. Simmons

9. Snlvage excavation at HeGee Bund Reservoir. Edward. B. Jelks

10. Tarly life in Periker County, Texas. Eddleman Pickard.

17. Ancient camp fires of Contral Texas. Albert Field

12. Some Upshur County pottery excavations. William Fovler

Figure 13. Program for 1956 TAS annual meeting in Waco. 


\section{November 20, 1956 ETAS Meeting}

The meeting was called to order by Mr. Henry Allen, Jr. Doug Proctor gave a brief report on the TAS Annual Meeting held in Waco. It was decided by the ETAS to keep in touch with the TAS for purposes of representation. A field trip was planned by the ETAS to visit Camp Fannin under the leadership of Mr. Leon R. Bailey.

A report on the Frankston site, which was not a society project, was given by Buddy Jones and L. A. Wallace. Mr. Wallace, in conjunction with Mr. Ray Vanderpool, said that they did not have permission to take the society as a group to the site but when the society set up the proposed museum that all the artifacts recovered by them from the site would be placed in the museum. No mention was made of Antonio A. Andretta, elected president of the ETAS.

\section{January 15, 1957 ETAS Meeting}

The meeting was called to order by Antonio A. Andretta. Only a few members were present since a special meeting had been called for January 20, 1957, on a planned program with Mr. W. W. Crook, Jr. and Mr. R. K. Harris of the Dallas Archeological Society to report on the site at Lewisville, Texas, with radiocarbon dates of 37,000 years.

Mr. Andretta also reported that a site in Quitman, Texas, to date, had yielded some 1,000 artifacts; more on this site was presented at the next meeting (see below).

\section{January 22, 1957 ETAS Meeting}

Mr. Antonio A. Andretta called the meeting to order. The planned program on the Lewisville site was canceled as neither Mr. Crook nor Mr. Harris were able to make it to Tyler.

Mr. Andretta then introduced the President of the Quitman Society, Dick Delk, who introduced their secretary, who read the minutes of their last meeting. The Quitman Society Field Chairman, Leo Speckman, then described the site in Quitman. No other record is made of the Quitman Society or the Quitman site.

Mr. Derrell Sanders then gave a report on Sam Whiteside's site on Prairie Creek (Smith County, Texas). He stated that the skeleton unearthed at the site was a female, about 25-28 years of age, and had apparently died of natural causes.

The books in the ETAS library were turned over to the ETAS librarian, Mrs. Betty Kashata.

The minutes of the meeting were "[d]isrespectfully submitted by Jen (Secretary-Treasurer: Jeanelle Proctor)." I am not sure what was meant by this statement by Mrs. Proctor, but this would seem to indicate that there was some dissension among members of the ETAS.

\section{April 16, 1957 ETAS Meeting}

Chairman Derrell Sanders turned the program over to John Mulligan and Sam Whiteside, who showed slides on the site on the Joe Meyer Estate located on Saline Creek, Smith County, Texas. Derrell Sanders summarized the progress made in the excavations of this site and commended Mr. Mulligan on his method of work. Several members registered sites with the society. 
Mr. Proctor moved the constitution be amended to provide for the annual election of officers to be moved to May rather than July for the year 1957 only. No mention was made of Mr. Andretta, the president of the ETAS.

\section{May 7, 1957 Meeting of the ETAS}

Chairman Sanders called the meeting to order. Minutes were read and a short report was given on excavations at the Meyer Estate site. The meeting was then turned over to Buddy Sanders and an Election Committee was created consisting of Sam Whiteside, L. A. Wallace, Billy Newman, John Mulligan, and Derrell Sanders. Again, there was no mention of Mr. Andretta.

\section{May 21, 1957 ETAS Meeting}

A quorum was not present. A motion was made to send a ballot and notification to current members. The Nomination Committee proposed the following slate of officers:

President: Doug Proctor

Vice-President: Billy Newman

Secretary-Treasurer: Derrell Sanders

Mr. Proctor appointed the following officers: Editor: Henry Allen Jones; and Field Chairman: Sam Whiteside. Upcoming programs were also announced: June 1957: Frank Byers program; July 1957: The Lewisville site presented by W. Crook and R. K. Harris; and December 1957: How to Go Crazy in One Easy Lesson in Archeology by E. Mott Davis.

Sometime during this period a brief history of the ETAS and its relation to other societies and universities was created (Figure 14). It is important to note that the ETAS in its creation formed close ties with the TAS; in fact, they considered themselves part of the TAS, receiving their charter from them. The ETAS was formed in June 1956 and in 90 days had 60 charter members. In 1955 there were nine TAS members in East Texas but by 1957 that number had risen to 36. Unfortunately, this relationship between the ETAS and TAS would cool through time.

Undoubtedly, there was a good deal of turmoil going on in the ETAS during 1957 and extending into 1958. There are scarce notes regarding meetings or activities of the ETAS during this period. One thing seems clear, and that is that Mr. Andretta was no longer involved in the ETAS. Little information remains about Mr. Andretta, such as where he came from or what happened to him following his brief stint as president of the ETAS. A Google search revealed that Antonio A. (Tony) Andretta (1927-1994) was at some point in time an amateur archaeologist in the Trans-Pecos region of Texas. He was also listed as Director of the Southwest Federation of Archaeological Societies, based in Alpine, Texas. He had a wife and daughter that were also members of the ETAS. 


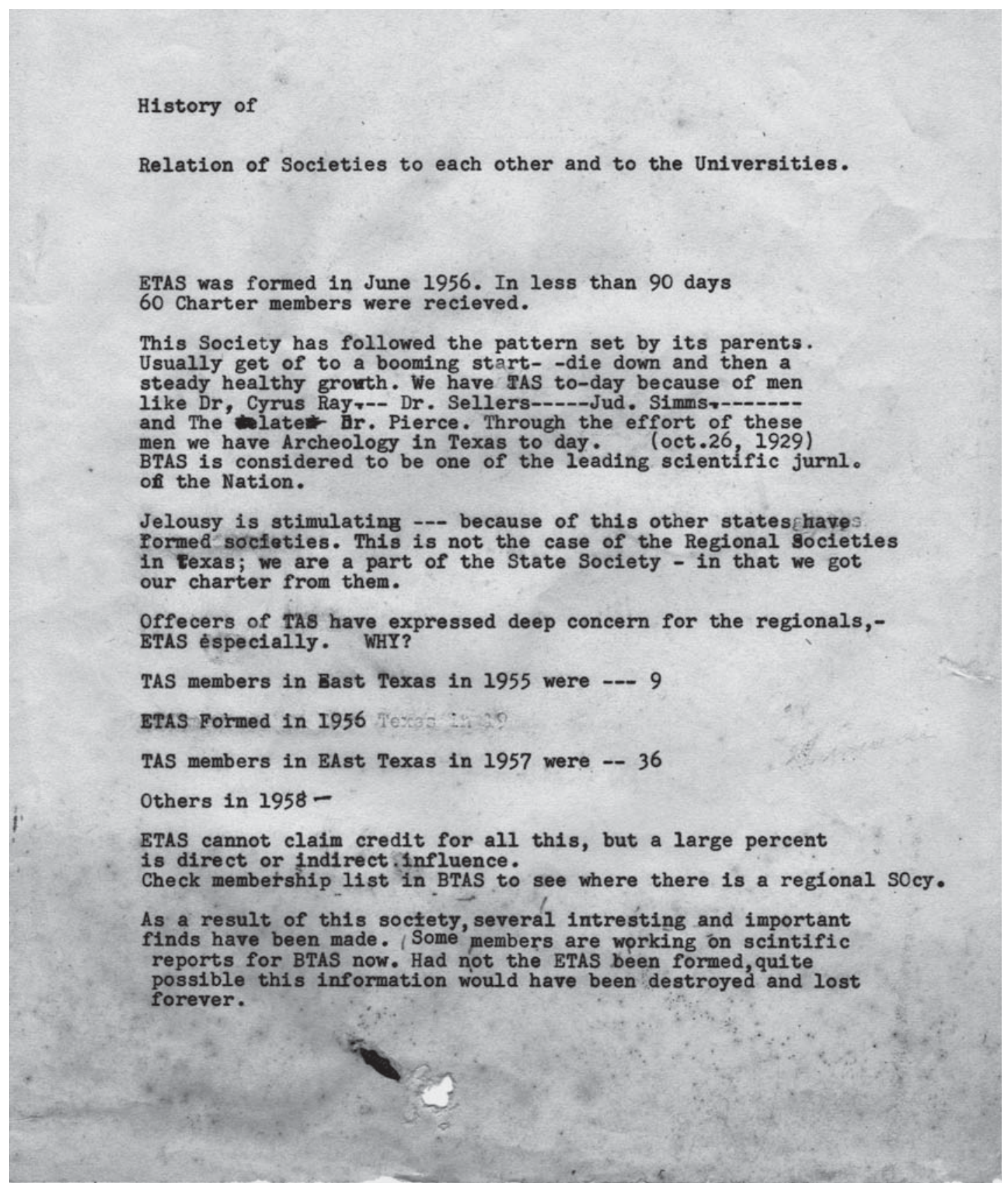

Figure 14. Brief history of the ETAS.

July 1957 ETAS Meeting

In attendance were:

Sam Whiteside: President

Billy Newman: Vice-President

E. W. Hayner

Bob Bragdan and friend

John Mulligan

Norman Bedgood

Alvin Davis 
Dan Henderson

George Kruger

Fred Pugh and wife

Loretta Johnston

In early spring, about March 1958, a resolution was passed to cancel all monthly meetings until further notice. President Doug Proctor refused to accept dues as there was no immediate need for funds.

\section{July 1958 ETAS Meeting}

Officers elected in the July Annual Meeting were: President: Sam Whiteside; Vice-President: John Mulligan; and Secretary-Treasurer: Janelle Proctor. A resolution was made to pay necessary expenses of the TAS meeting out of the treasury. The TAS Annual Meeting was held at the Carlton Hotel in Tyler on November 7-9, 1958.

\section{CONCLUSIONS}

Following the successful 1958 TAS meeting held in Tyler, Texas, the ETAS began to fade from existence. This was the last formal function held by the ETAS. The next information from the ETAS is from the April 1959 publication of their newsletter, Ancient News (Vol. 1, No. 1). There was discussion in the newsletter about the 1958 TAS meeting and the fact that dues had not been collected for some time. A suggestion was made to lower the dues of $\$ 5$ per year to $\$ 1$ per year. After the TAS meeting expenses, the ETAS had a bank balance of $\$ 46.53$. This was the last bank transaction taken by the ETAS. There was a statement from the bank in June 1966 indicating the account was still open at $\$ 46.53$, but inactive at that time. No further records exists concerning this bank account.

No mention was made in the newsletter of current officers but Sam Whiteside was still active as indicated by a short progress report on his work conducted at the Bryan Hardy site (41SM55). Evidently he was in charge of publishing the newsletter as well. A meeting of the ETAS was scheduled for April 2, 1959, to discuss dues and other matters.

In the July 1959 addition of Ancient News (Vol. 1, No. 2), the April 1959 ETAS meeting was discussed. The merits of the ETAS were also discussed, noting that the society had accomplished a lot. Several members were active and preparing papers on sites. Also, due to the ETAS the TAS had shown considerable growth in East Texas, growing from nine East Texas members to 36 by 1957. L. A. Wallace acted as secretary and the bylaws were amended to lower the dues to $\$ 1$ per year. The dues were to be mailed to Sam Whiteside. There were a total of 22 current members. E. W. Hayner from Kilgore brought artifacts to the April meeting to show to the group.

July 1959 marked the fourth year of the ETAS and the next scheduled meeting was called for July 16 , 1959 at the Courier Times Building in Tyler. A closing note in the July 1959 newsletter announced that Buddy Jones of Longview had opened a museum to display his large collection of artifacts, including Titus focus (now Titus phase) material and two reconstructed burials.

The July 1959 issue of Ancient News is the last record available for the ETAS. Due to Sam Whiteside's illness, he was no longer able to carry on and evidently there was no one else willing to step forward. It is remarkable nevertheless that there was such an interest in East Texas archaeology at the time of its inception. Recent attempts to form another archaeological society in Tyler have met with dismal results. Maybe the population surrounding Tyler in the mid-1950s was more rural, with more farming, and there were more chances to observe artifacts in plowed fields than present. Perhaps also people were more aware of 
their surroundings and curious about artifacts found on sites in East Texas that represented occupations by earlier peoples. In its brief four year life, the ETAS had great ambitions, some partially realized, others not. Such is life.

\section{REFERENCES CITED}

Perttula, T. K., with contributions by D. E. Wilson and M. Walters

2006 A Study of the Buddy Calvin Jones Collection from Northeast Texas Caddo Sites. Special Publication No. 6. Friends of Northeast Texas Archaeology, Pittsburg and Austin.

Walters, $\mathrm{M}$.

2004 A Profile in East Texas Archeology. Bulletin of the Texas Archeological Society 75:119-121.

2012 Join us for the 83rd Annual TAS Meeting in Tyler on October 25-28! Texas Archeology (The Newsletter of the Texas Archeological Society) 56(4). 


\section{APPENDIX 1, JUNE 15, 1956 ANNOUNCEMENT}

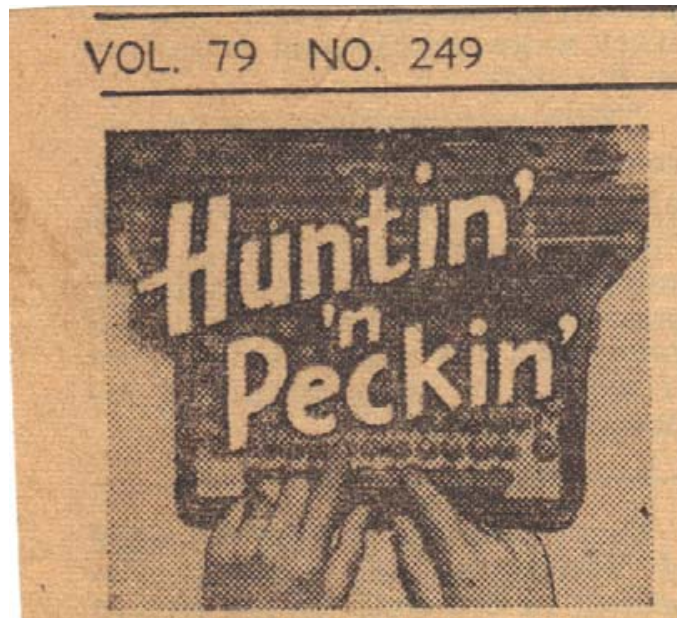

BY EVERETT TAYLOR JR. Manazins Editor, Courier-Times-Telegraph Hats off today to dad. A happy father's day to every one.

For those who like to dig into the past (literally or figuratively), a meeting of prime importance is upcoming Monday, June 26, at 8 p.m. in the meeting room of the Courier-Times-Telegraph building.

On that date the East Texas Archeological Society will be formed, if plans of a group headed by A. A. Andretta are realized.

Andretta explains the society is being formed by amateurs, for amateurs with like interests.

Purpose of the society will be to encourage the study of archeoology in East Texas adjacent regions; the proper collection, preservation and interpretation of artifacts and other remains of the native triest of this region and the creation and publication of researclfes relating to this.

Arrangements bave been made for the local society to join the Texas Archeological Society, affording professional help and research facilities, as well as guidance and assistance from noted people in the field of Archeology.

There probably are many amateur collectors in this section who will be interested in taking part in the new organization. 
APPENDIX 2, ETAS SPECIAL MEETING, JULY 10, 1956

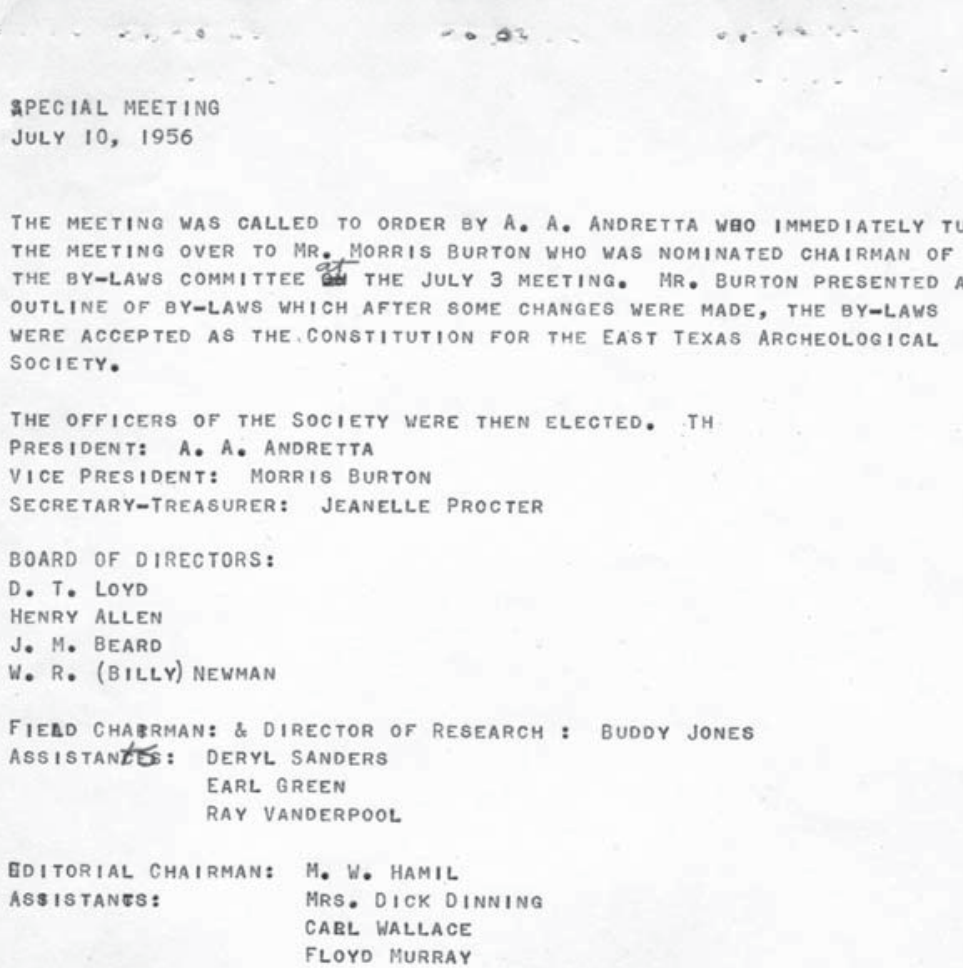

IT WAS DECIOED THAT THE REGULAR MEETING WOULO BE HELO ONCE A MONTH, ON THE THIRD TUESDAY OF THE MONTH AT 8 P.M. IN THE GOURIER-TIMES BUILOING. MEMBERS WILL RECEIVE NOTIFICATION OR REMINDERS OF THE MEETING.

THE MEETING WAS THEN TURNED OVER TO BUDDY JONES WHO GAVE A VERY INTERSTING TALK AND DISPLAYED SOME OF THE POTTERY AND OTHER ANCIENT ITEMS HE HAD UNEARTHED IN GREGG COUNTY.

Mr. ANDRETTA ADJERnEd THE MEETING.

DUES WERE COLLECTED. 


\section{APPENDIX 3, ETAS BYLAWS}

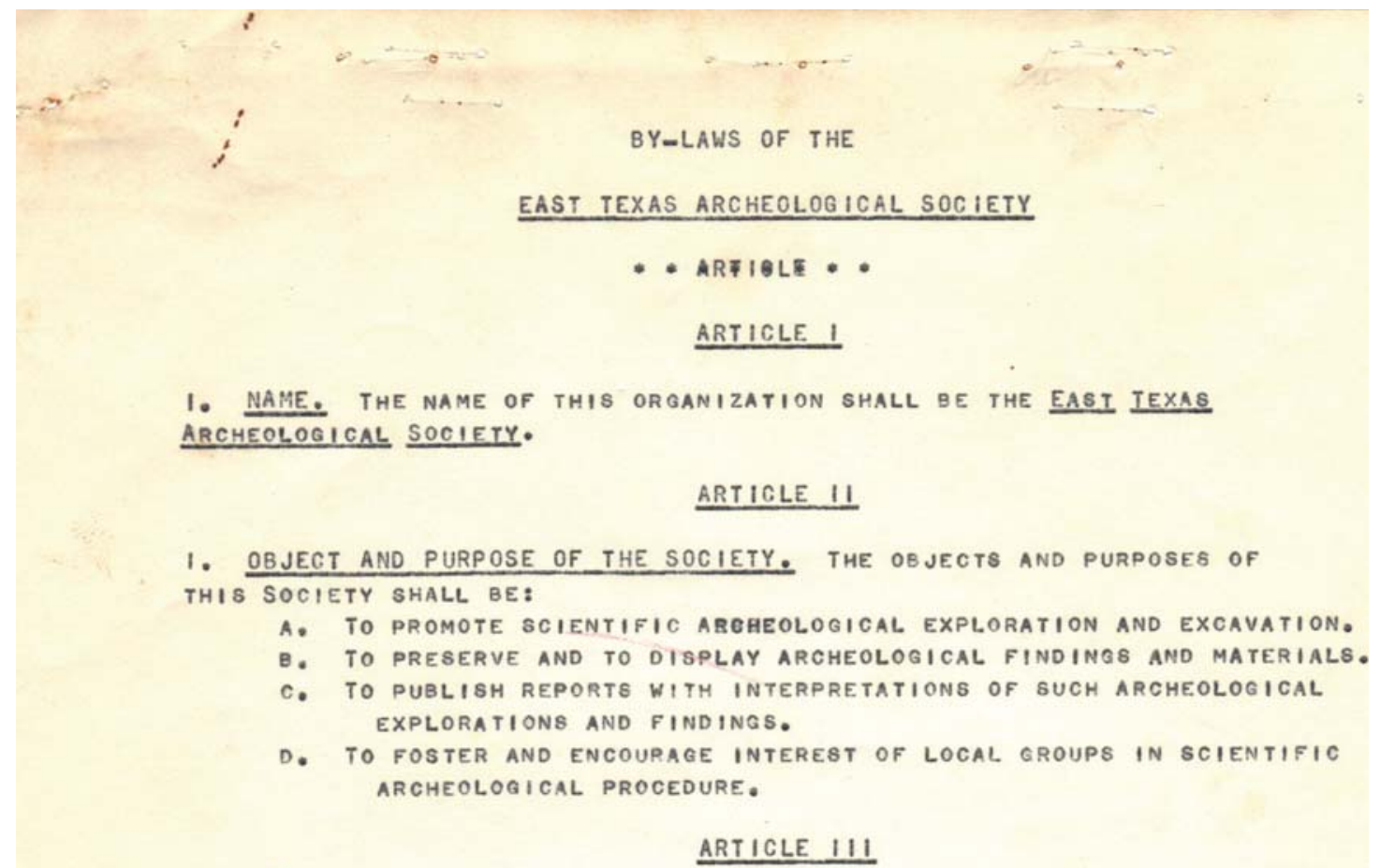

MEMBERSHIP

1. MEMBERSHIP IN THIS SOCIETY SHALL BE UNLIMITED.

2. ANY MAN, WOMAN OR CHILO (ABOVE THE AGE OF I4 YEARS RESIDING IN EAST TEXAS SHALL BE ELIGIBLE FOR MEMBERSHIP IN THIS SOCIETY. ALL MEMBERS WILL BE VOTED ON. ANY MEMBER WHOSE DUES ARE PAID WILL BE ELIGIBLE TO VOTE. FOR THE PURPOSE OF DEFINING EAST TEXAS, IT IS THAT AREA EXTENDING EAST OF A LINE DRAWN NORTH THROUGH WACO, TEXAS, AND NORTM OF A LINE. DRAWN EAST THROUGH THE SAME CITY, EXTENDING TO THE NORTHERN AND EASTERN BOUNDARIES OF THE STATE OF TEXAS.

3. THERE SHALL BE THREE CLASSES OF MEMBERSHIP - CHARTER MEMBER, MEMBER AND HONORARY MEMBER. A CHARTER MEMBER SHALL BE ANY MEMBER OF THE SOCIETY JOINING WITHIN 90 DAYS AS OF JUNE 25, 1956. A MEMBER SHALL BE ANY MEMBER JOINING THEREAFTER. AN HONORARY MEMBER SHALL BE AS DEFINED IN SECTION 6 OF THIS ARTICLE. LAN APPLICANT FOR MEMBERSHIP, EITHER CHARTER OR MEMBER, MUST PRESENT AN APPLICATION (VERBALLY OR IN WRITTNG) TO THE SECRETARY, WHO SHALL NOTIFY THE SOCIETY OF SUCH APPLICATION AT ITS NEXT REGULAR MEETING. THE MEMBERSHIP PRESENT AT SUCH NEXT REGULAR MEETING SHALL. VOTE UPON ADIAISSION BY MAJORITY VOTE. IF AFFIRMATIVE, SAID APPLICANT SHALL BE NOTIFIED OF SUCH ADMISSION AND BE DECLAREO A CHARTER MeMBer OR MEMBER.

4. DUes shall be \$5.00 per year for Charter Members and Members. $y^{2}$ DUES ARE PAYABLE ANNUALLY IN ADVANCE ON OR BEFORE JUNE 26 , OF EACH YEAR. THE SECRETARY-TREASURER SHALL NOTIFY MEMBERS TWO MONTHS IN ARREARS ON DUES PAYUENT, AND IF NOT PAIO WITHIN SIXTY DAYS THEREAFTER, SAID MEMBER SHALL BE AUTOMATICALLY DROPPED FROM THE ROLL OF MEMBERSHIP OF THE SOCIETY, 5. CHARTER MEMBERS AND MEMBERS SHALL hAVE ALL OF THE PRIVILEgES OF THE SOCIETY INCLUDINE THE MAKING OF MOTIONS, OF VOTING AND OF HOLOING OFFICE. 


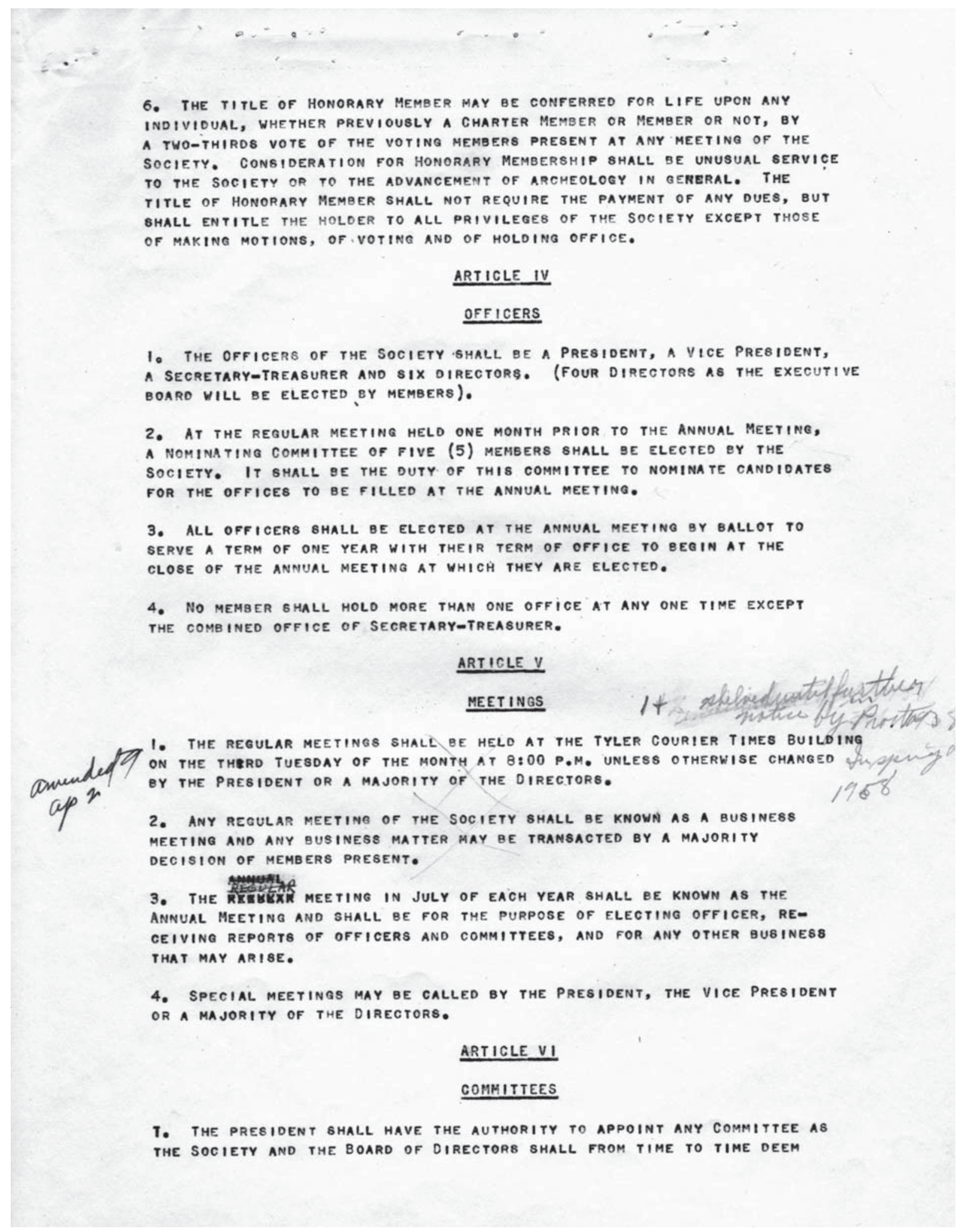




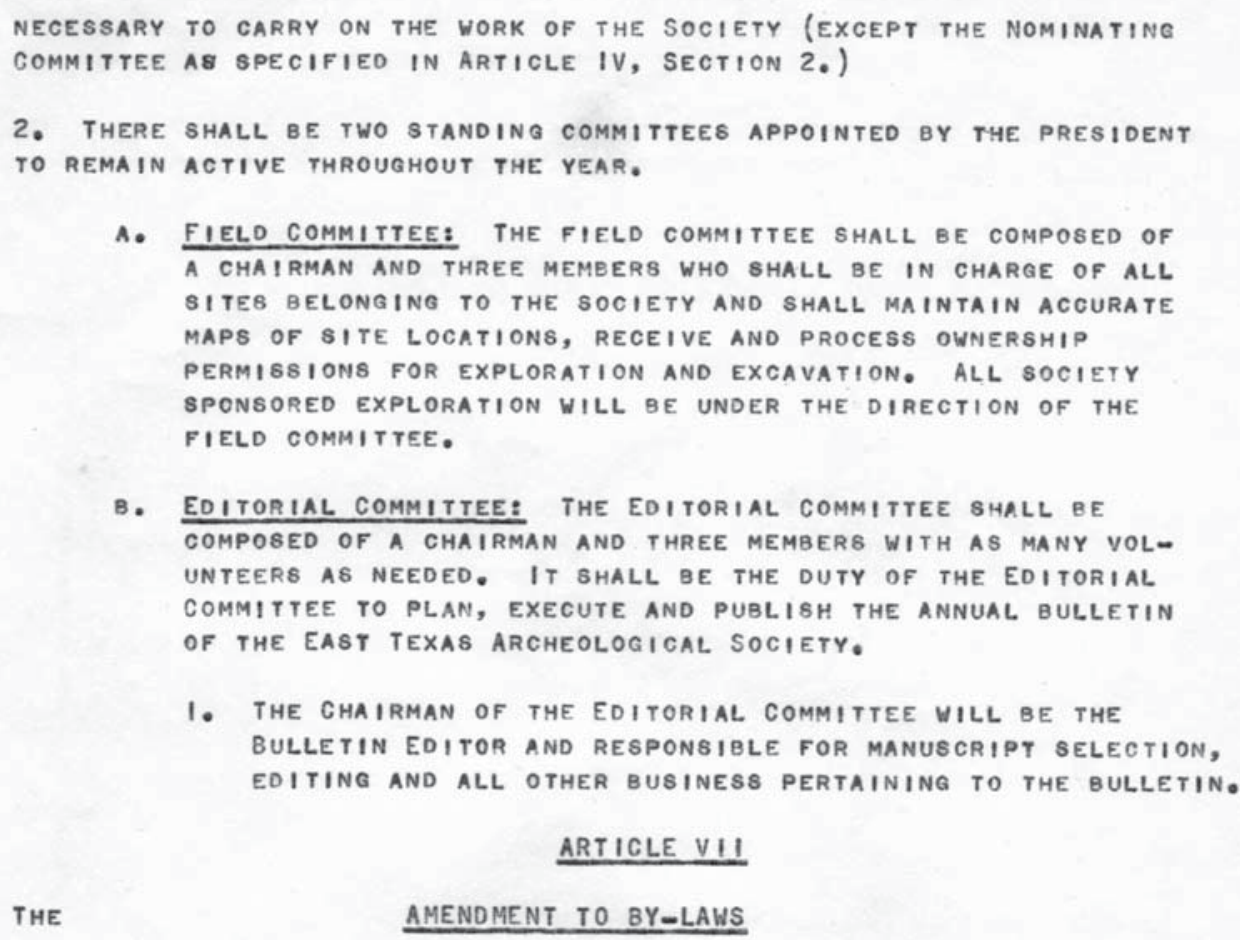

A. Fielo COMMITTEE: THE Field commitTEe Shall be composed of A CHAIRMAN AND THREE MEMEERS WHO SHALL BE IN CHARGE OF ALL SITES BELONGING TO THE SOCIETY AND SHALL MAINTAIN ACCURATE MAPS OF SITE LOCATIONS, RECEIVE AND PROCESS OWNERSHIP PERMISSIONS FOR EXPLORATION AND EXCAVATION. ALL SOCIETY SPONSORED EXPLORATION WILL BE UNDER THE DIRECTION OF THE FIELD COMMITTEE.

B. EDITORIAL COMMITTEE: THE EOITORIAL COMMITTEE SHALL BE COMPOSED OF A CHAIRMAN AND THREE MEMBERS WITH AS MANY VOLUNTEERS AS NEEDED. IT SHALL BE THE DUTY OF THE EDITORIAL COMMITTEE TO PLAN, EXECUTE AND PUBLISH THE ANNUAL BULLETIN OF THE EAST TEXAS ARCHEOLOGICAL SOCIETY.

1. THE GHAIRMAN OF THE EDITORIAL COMMITTEE WILL BE THE BULLETIN EDITOR AND RESPONSIBLE FOR MANUSCRIPT SELECTION, EOITING AND ALL OTHER BUSINESS PERTAINING TO THE BULLETIN.

\section{ARTICLE VII}

THE AMENDMENT TO BY-LAWS

THESE BY-LAWS MAY BE AMENDED AT ANY REgULAR MEETING OF THE SOCIETY BY A TWO-THIRDS VOTE, PROVIDEO THE AMENDMENT HAS BEEN SUBMITTEO IN WRITING AT THE PREVIOUS REGULAR MEETING.

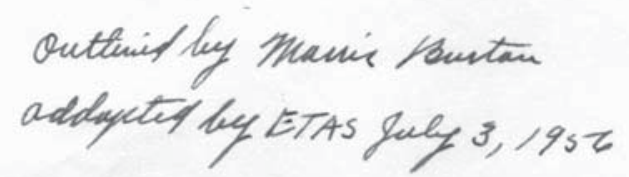




\section{APPENDIX 4, EAST TEXAS ARCHEOLOGICAL SOCIETY CHARTER MEMBERS}

ETAS Foundation Meeting, June 26, 1956, Charter Members, Dues \$5.00

1. W. L. Lowthrope

2. Mr. and Mrs. D. T. Loyd

3. Daniel L. Glenn

4. Wilson W. Turbyfill

5. E. W. Turbyfill

6. Geo. H. Adams

7. George F. Krueger

8. L. A. Wallace

9. Jerry Davis

10. Harry Allen, Jr

11. Mary S. McDonald

12. A. T. McManns

13. J. L. Jones

14. Buddy Jones

15. John J. Wallis

16. F. Earl Green

17. W. R. (Billy) Newman

18. Earl Guinn

19. Bette Kashata

20. C. Tompleson

21. D. E. Proctor

22. Floyd Murray

23. R. L. Turner, Jr.

24. Waymond V. Wilson

25. R. R. Nicholas

26. Ed. German

27. Dick F. Lowe

28. Jim Kilmer

29. Morris S. Burton

30. Oren M. Murphy

31. G. G. Andretta

32. Jeanelle Proctor

33. Donna Andretta

34. Alice Heidrick

35. Hugh W. Heidrick

36. J. M. Beard

37. Derrell W. Sanders

38. Travis M. Smith

39. G. R. Dennis

40. Don A. Dickson

41. Billie Jean Sanders

42. Beecher Davis, Jr.

43. Paul Knife
Tyler, TX

Gilmer, TX

Palestine, TX

Palestine, TX

Palestine, TX

Frankston, TX

Hawkins, TX

Tyler, TX

Tyler, TX

Tyler, TX

Tyler, TX

Brownsboro, TX

Longview, TX

Longview, TX

Tyler, TX

Tyler, TX

Tyler, TX

Tyler, TX

Tyler, TX

Tyler, TX

Tyler, TX

Tyler, TX

Pittsburg, TX

Hughes Springs, TX

Daingerfield, TX

Lone Star, TX

Greenville, TX

Greenville, TX

Tyler, TX

Whitehouse, TX

Whitehouse, TX

Tyler, TX

Whitehouse, TX

Tyler, TX

Tyler, TX

Gladewater, TX

Tyler, TX

Tyler, TX

Tyler, TX

Tyler, TX

Tyler, TX

Tyler, TX

Overton, TX 
Those Desiring Admission - Not Attending First Meeting of ETAS

44. C. L. Beason

45. J. B. Carter

46. Henry Ogden

47. The Rt. Rev. F.P. Goddard

48. Dr. Albert Woldert

49. Ray Vanderpool

50. Omer Hood

51. Marshall W. Hamil

52. Bogie Price

53. Carson Kennedy

54. M. A. Richardson

55. Carl Wallace

July 10, 1956 Meeting of ETAS

1. Ray Vanderpool

2. Ted Price

3. Jan Burandt (friend of Buddy Jones)

4. J. M. Beard

5. Henry Ogden

6. G. R. Dennis

7. John David Zimmerman

8. Mrs. Beecher Davis

9. Derrell W. Sanders

10. Don A. Dickson

11. Mrs. R. W. Denning

12. Charlie Brannon

13. Monk Canterberry

14. M. W. Hamil

15. Joyce Hamil

16. Robert W. Reed
Beckville, TX

Beckville, TX

Paris, TX

Tyler, TX

Tyler, TX

Tyler, TX

Jacksonville, TX

Tyler, TX

Atlanta, TX

Gladewater, TX

Tyler, TX

Tyler, TX
Tyler, TX

LaRue, TX

Longview, TX

Gladewater, TX

Paris, TX

Tyler, TX

Hughes Springs, TX

Tyler, TX

Tyler, TX

Tyler, TX

Kilgore, TX

Kilgore, TX

Kilgore, TX

Tyler, TX

Tyler, TX

Tyler, TX

July 17, 1956 Meeting of ETAS

1. Felicia M. Andretta

2. A. A. Andretta

3. W. M. Walters

4. Mrs. R.N. Scott

5. Mrs. Sue Wehrli

6. Philip Whiteside

7. Sam Whiteside

8. Morris Burton

9. J. B. Price

10. Mrs. J. R. Herbert

11. R. L. Turner

12. Ed. German

13. Trudie Bryant

14. Fred W. Horton

15. Sam Garcia, Jr.

16. Mrs. Sam Garcia, Jr.

Kilgore, TX

Kilgore, TX

Tyler, TX

Tyler, TX

Atlanta, TX

Greenville, TX

Pittsburg, TX

Lone Star, TX

Athens, TX

Greenville, TX

Lufkin, TX

Lufkin, TX 
17. Patricia Garcia, Jr.

18. John Mulligan

19. Bob Brogden

20. Ray L. Thompson

21. E. W. Hayner

September 18, 1956 Meeting of ETAS

1. Mike Miller

2. Trudie Bryant

3. John Mulligan

4. Mrs. Sue Wehrli

5. Mrs. R. N. Scott

6. Mr. \& Mrs. Paul L. Hughes

7. Leon R. Bailey

ETAS Paid Members 1957, Dues \$5.00

1. John Mulligan

2. Sam Whiteside

3. Douglas Proctor

4. Janelle Proctor

5. Carrie Whiteside

6. Earl Guinn

ETAS Paid Members 1959, Dues \$1.00

1. Bill Newman

2. Ray Vanderpool

3. L. G. Wallace

4. John D. Mulligan

5. Bob Bragdan

6. E. W. Hayner

7. Norman G. Bedgood

8. Geo. F. Krueger

9. Jenny Krueger

10. Sam Whiteside

11. Earl Guinn

12. Alvin R. Doris

13. W. T. Lawthrop

14. Carson Kennedy

15. Jim Whiteside

16. Mark Walters

17. Robert Brooks

18. John J. Dieckman

19. Doug E. Proctor

20. Jeanelle Proctor

21. D. W. Sanders

22. Jerry Vanderpool

23. Jan Burandt
Lufkin, TX

Tyler, TX

Tyler, TX

Karnack, TX

Kilgore, TX

Kilgore, TX

Odessa, TX
Troup, TX

Winona, TX

Winona, TX

Houston, TX 


\section{APPENDIX 5, AUGUST 1956 CARY LAKE CAVE EXCAVATION RULES}

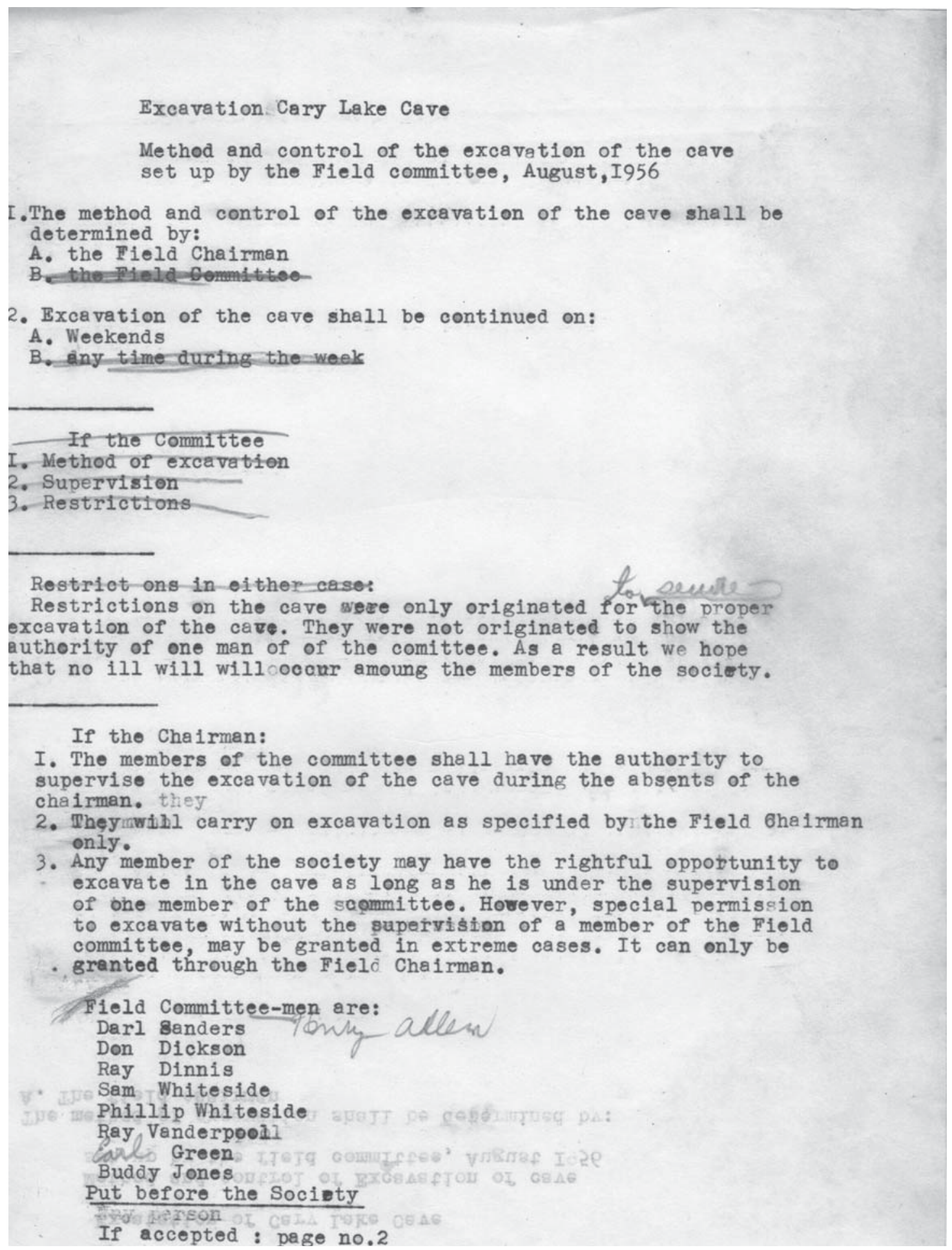


Excavation Rules of Cary Lake Cave

I. Any member who fails to abide by these rules will be:going against the purpose of the society, thus he should not have joined the society. ormembers by

2. Any member who fails to abide these fules set up by the-fField Chár $\mathrm{m}+$-the comittee; (the seneleby-) and accepted by the society: will have his membership voted uponbbyttheBBeard of Directers.

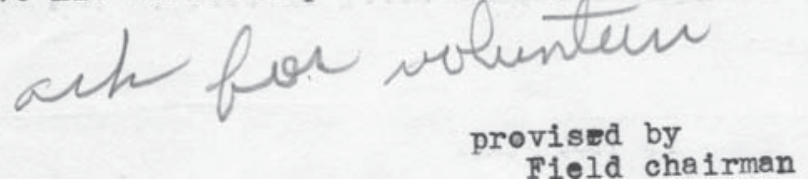


APPENDIX 6, JULY 31, 1957 LETTER FROM E. MOTT DAVIS

\section{THE UNIVERSITY OF TEXAS AUSTIN 12}

Mr. Sam Whiteside

Route 1

Tyler, Texas

Dear Mr. Whiteside:

I was delighted to get your preliminary report on the burials in Sites P-2 and P-4 in eastern Smith County. Judging from the evidence you present, I am inclined to agree that the evidence for positive association of the buria: with the Alto Focus material is pretty slim--which is a shame, when you consider how we are aching for some good Alto Focus burials.

This report will go in our Smith County files. I look forward to seeing your final report, in which I trust you will include illustrations of the artifacts. If you need any help (e.g. photographic), we would be glad to do what we can. One thing would like to know, is the precise location of the sites, so that we can spot them on our County Road maps. We keep a card file of all sites in the state, with references to the maps and to notes and specimens. This is a study file for serious students, not for people who will go out and root around for relics.

I have been wanting to show your report to Ed Jelks, and to get his comments on your finds, since he has had a lot of experience in East Texas whereas I have only put in one field season there so far. However, he has been away, and rather than wait any longer, I am acknowledging your report.

May I say that your statement is a first-class preliminary report, really useful to others working on East Texas archeology. When your full report is done, we must see what can be done toward publication.

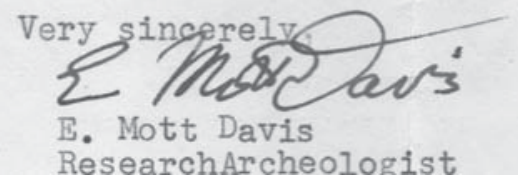


APPENDIX 7, AUGUST 9, 1957 LETTER FROM LEROY JOHNSON, JR.

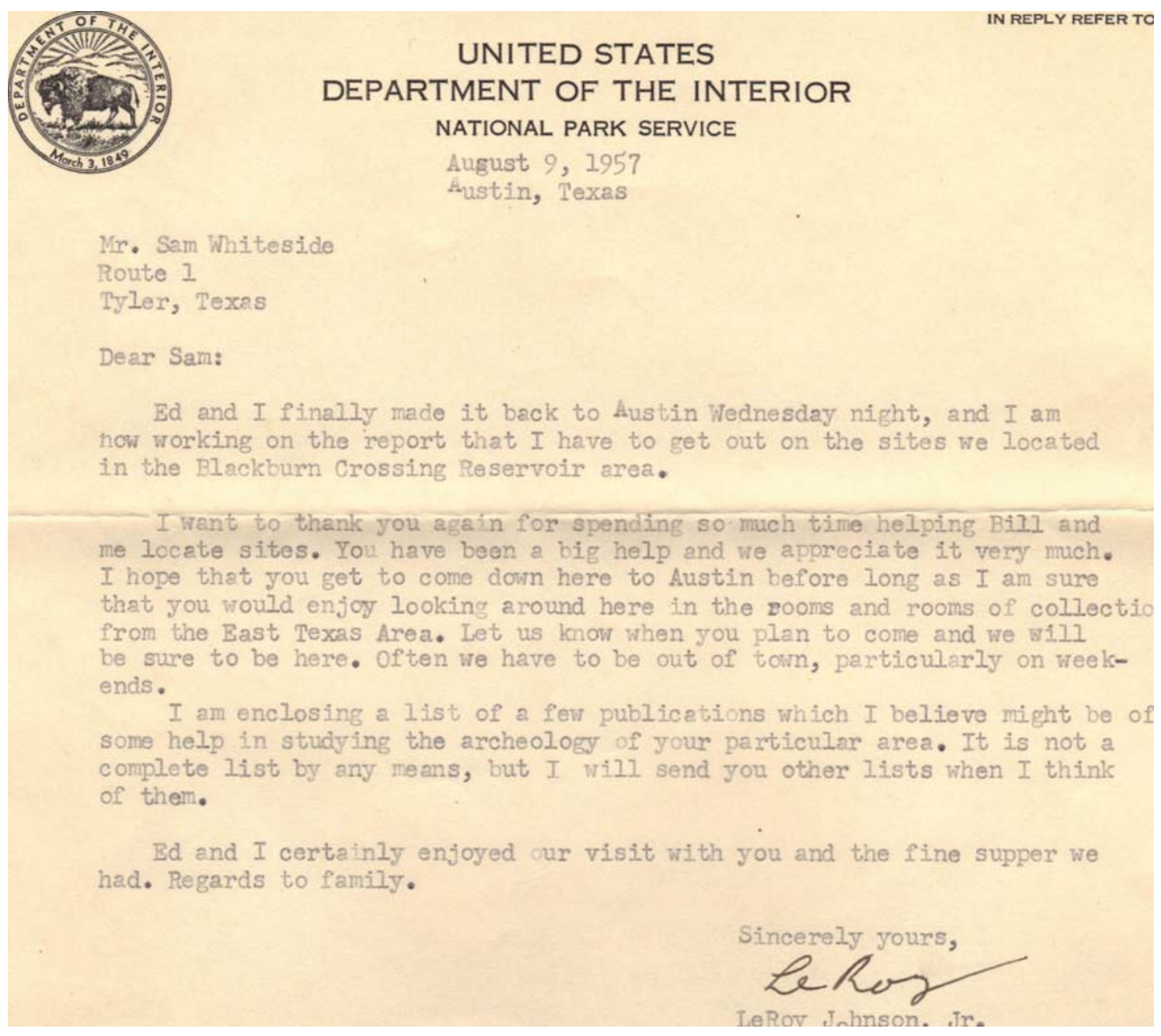


APPENDIX 8, DECEMBER 12, 1957 LETTER FROM E. MOTT DAVIS

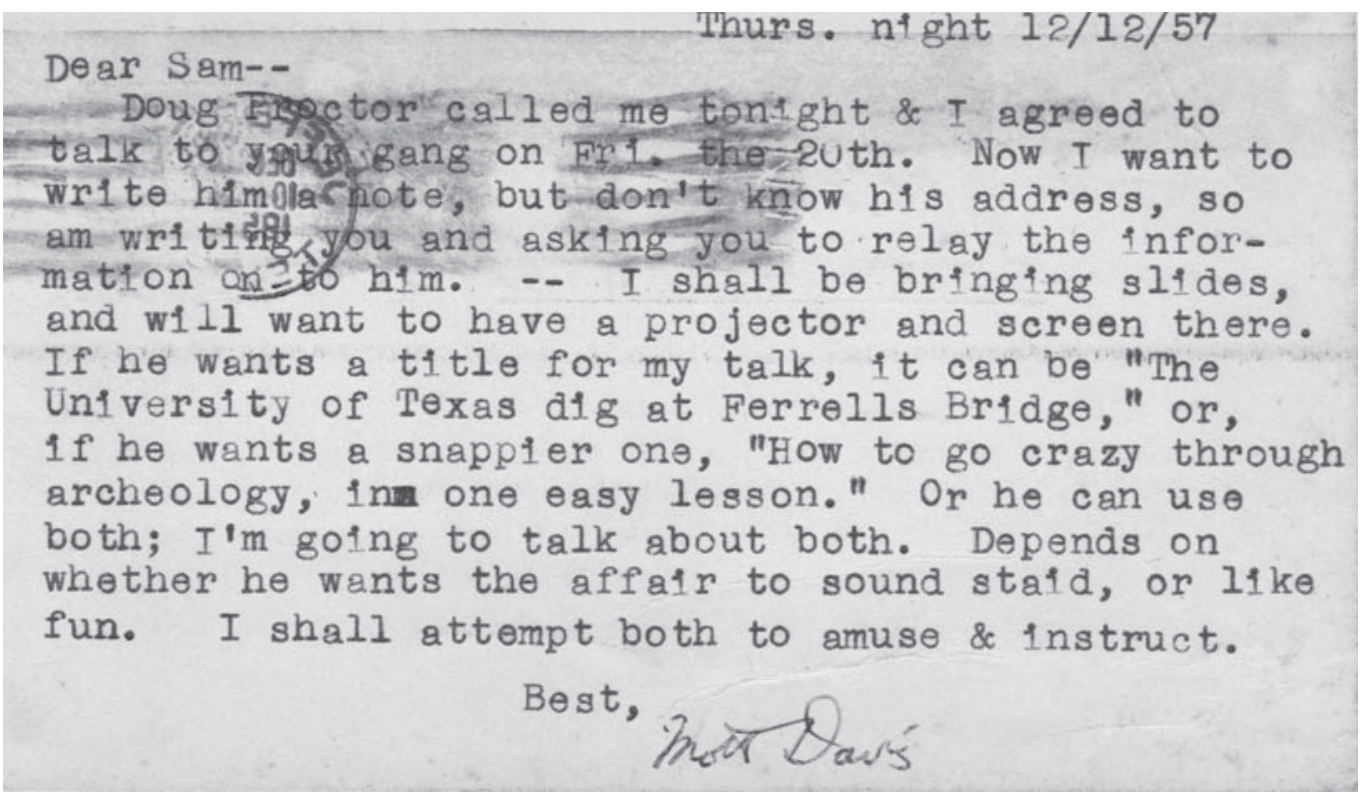


Journal of Northeast Texas Archaeology 47 (2014) 75

APPENDIX 9, FEBRUARY 17, 1958 LETTER FROM EDWARD B. JELKS

6004 Belfort binge Austin, Sects February 17, 1958

Lear Sam,

Gust a note thank you for the saves. 2 finally got them all ut out but was beginning to sum out of stan trows the end. I didn't expect so many but was glad to get them.

I hove been busy writing a report on the 19u6 dig at Mc the Rind which 2 hope to have completed in the rept mouth or so. And we are still washing and cataloging the materiel from last fill.

Why dost you come down Curtin again. Mott has all the pots from the boils ot Fenclli Bridge pit together and I an sure you world enjoy seeing then, as well as some f the other things. keep us posted ow whit is going on aromas by les.

With but regal. Sincerely,

ce l 


\section{APPENDIX 10, MARCH 31, 1958 LETTER FROM E. MOTT DAVIS}

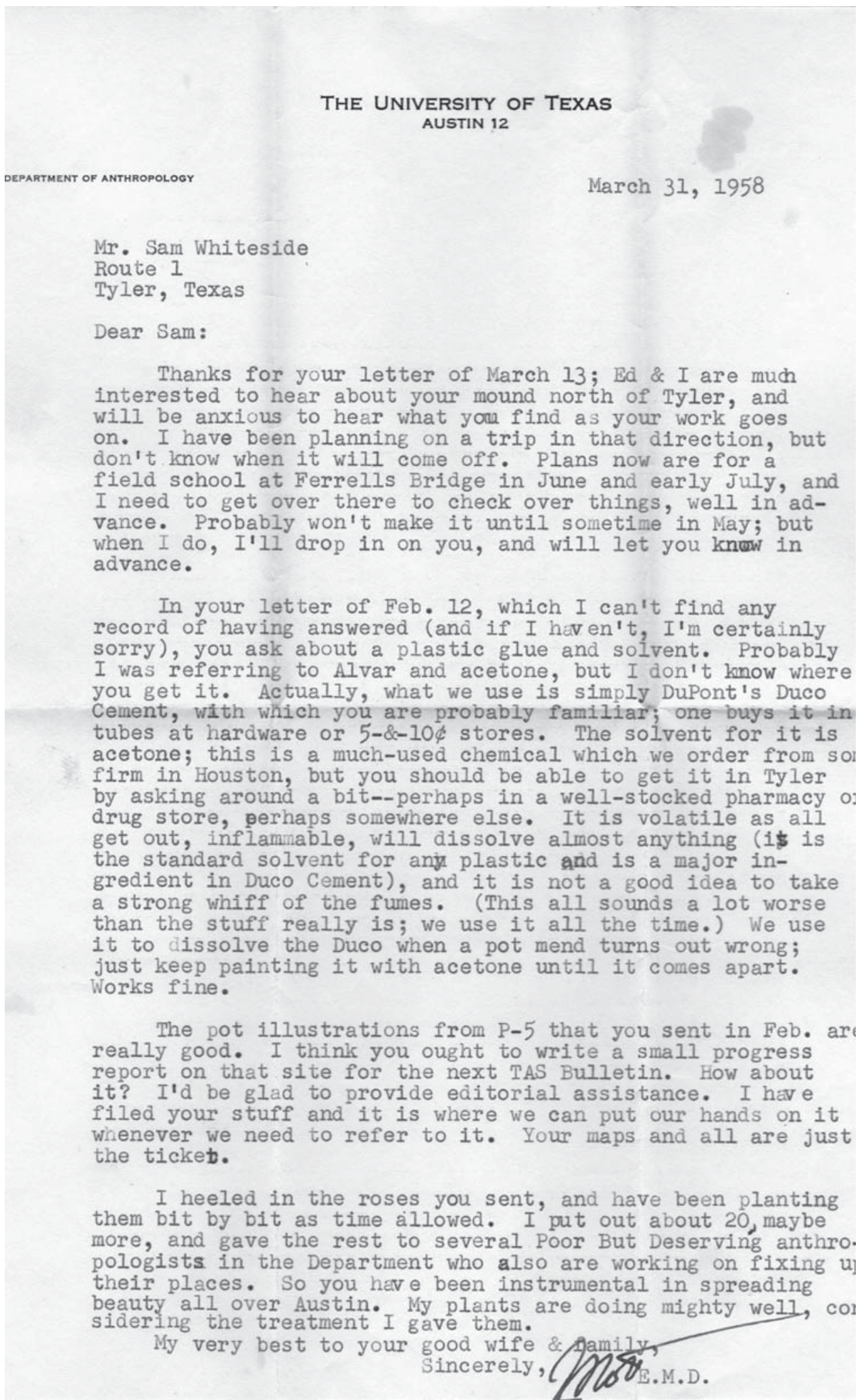




\section{APPENDIX 11, JUNE 21, 1958 LETTER FROM E. MOTT DAVIS}

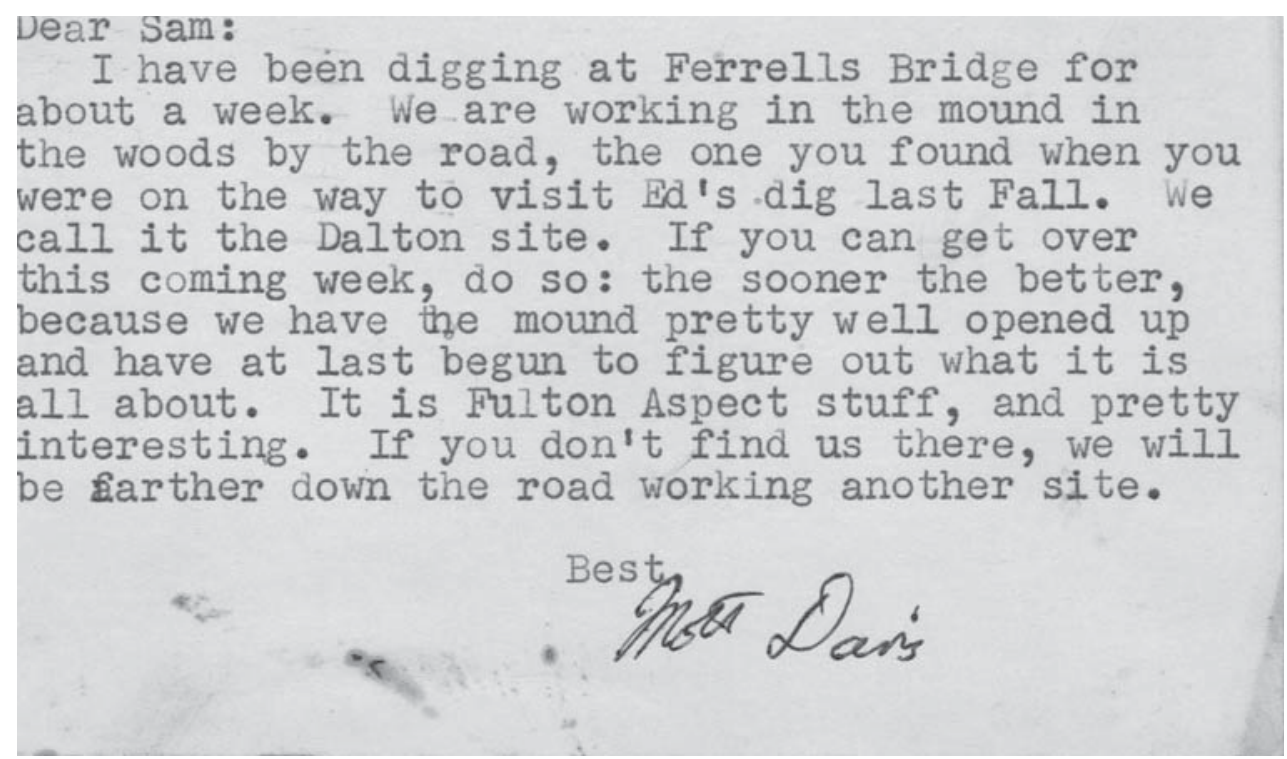




\section{APPENDIX 12, APRIL 1959 ETAS NEWSLETTER}

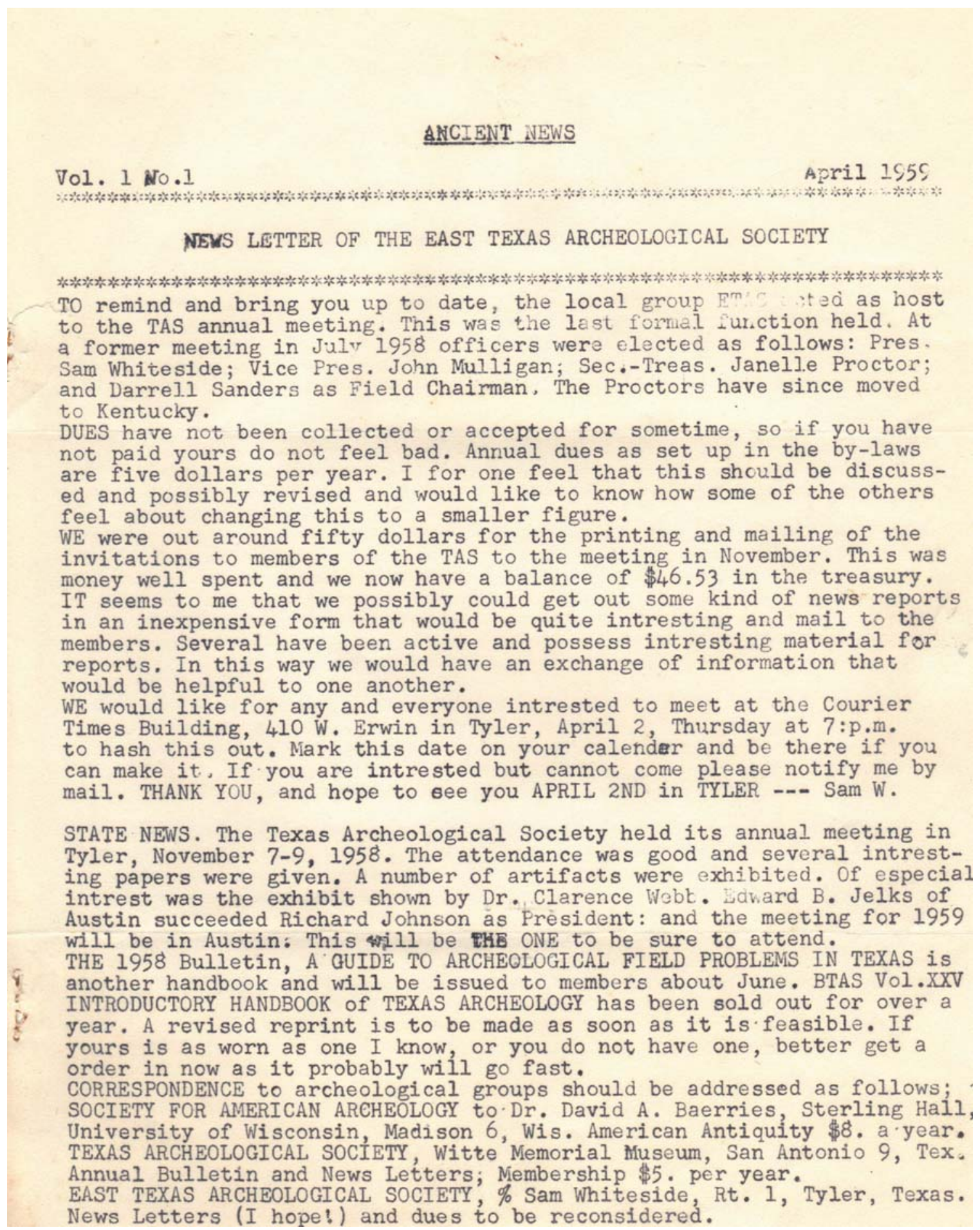


OR. E. I.OTT DAVIS with the Universityof l'exas has been exploring the Ferreli's Bridge Reservoir and has good information concerning tha earlier phase of the Titus Foxus. I am sure that his report on this will be very informative and of intrest to many.

$* * * * *$

*****

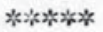

*****

**2*\%

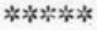

THIS is a vessel recenstructed by sherds from the Bryan Hardy Site on which I have been working. INCISED ware: Rins-triangles filled with punctates, triangles with the corners rounded by oets of paralell lines. Another ressel had panels of paralell lines alternating with punctates between the panels. Bodies of vessels were brushed with fingernil punctates at -andom through the brushing. Ed Jelks comments, "It is especially striking - see many sherds with characteristically Fulton Aspect brushed backround and characteristically Alto Focus punctatine." Some sanclers Focus raits are present also.Brushed incised sherds froli this site is abcut swenty percent. A detailed report on this site is in the mill.

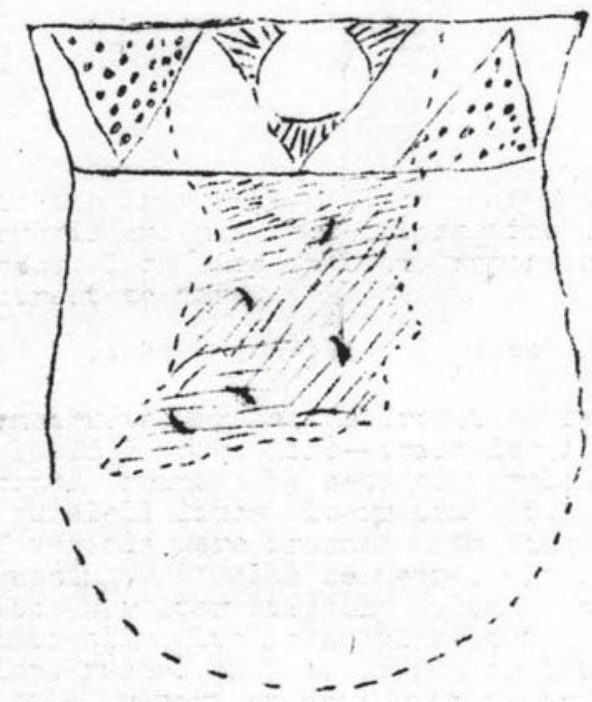

$1 / 3$

THE A. C. SAUNDERS SITZ in Anderscn County, cne of the key sites used in defining the Frankston Focus, has a 58 . cised sherds (BTAS Vol.8). I have seen sevral sites, on the upper Sabine and Neches Rivers, that have a small amount of bmishing, with mostly Ciboon Aspect traits in cermmic desion, t 5 tiat with the increase in percentage of brushinr, othes fulcor susect traits jecome more apparent. James A. Ford has very vell demonstrated the use of popularity of dosign and other traits to s'on relation of culture seouence in the lississippi area. Brushing 13 virtuelly absent in the ibson Aspect. Perhaps the percentare of brusiling vould be nre incizaion of the relationship. 


\section{APPENDIX 13, 1958 TEXAS ARCHEOLOGICAL SOCIETY ANNUAL MEETING, TYLER, TEXAS}

1. John Lewis

2. Kenneth Owen

3. Thomas Barr

4. Floyd Sharrock

5. B. Eubank

6. J. Mulligan

7. E. E. Jackson

8. Mott Davis

9. Mr. \& Mrs. D. Johnson

10. Robt. Stevenson

11. Bob Turner

12. Lathael Duffield

13. W. A. Davis

14. Sam Whiteside

15. Dr. Clarence Webb

16. W.L. Everett

17. C.L. Edgar

18. Ed. Jelks

19. Tommy Lawthrop

20. Dick Clardy

21. C. Steen

22. Walt Taylor

23. G. F. Krenger

24. Hayner

25. Isabelle Lobdell

26. G. W. Turbyfill

27. L. A. Wallace

28. D. J. Smelley

29. Dr. M. E. Huff

30. Dr. Compton

31. Bob Brogden

32. R. H. Tull

33. N. G. Bedgood

34. Frank Sloan

35. H. N. Cobb

36. R. L. Turner

37. R. S. Redding

38. Elizabeth Pillaert

39. Mark Walters

40. Loyd Harper

41. Judge O. L. Simms

42. Richard Gene Wood

43. M. Shutye

44. Dr \& Mrs. Ray

45. Ray Vanderpool

46. D. T. Loyd

47. K. King

48. Billy Newman
University of Oklahoma

University of Oklahoma 
APPENDIX 14, TAS PROGRAM, NOVEMBER 7-9, 1958 ANNUAL MEETING IN TYLER, TEXAS

TEXAS ARCHEOLOQICAL SOCIETY PROGRAM NOVEMBER $7-9,1958$

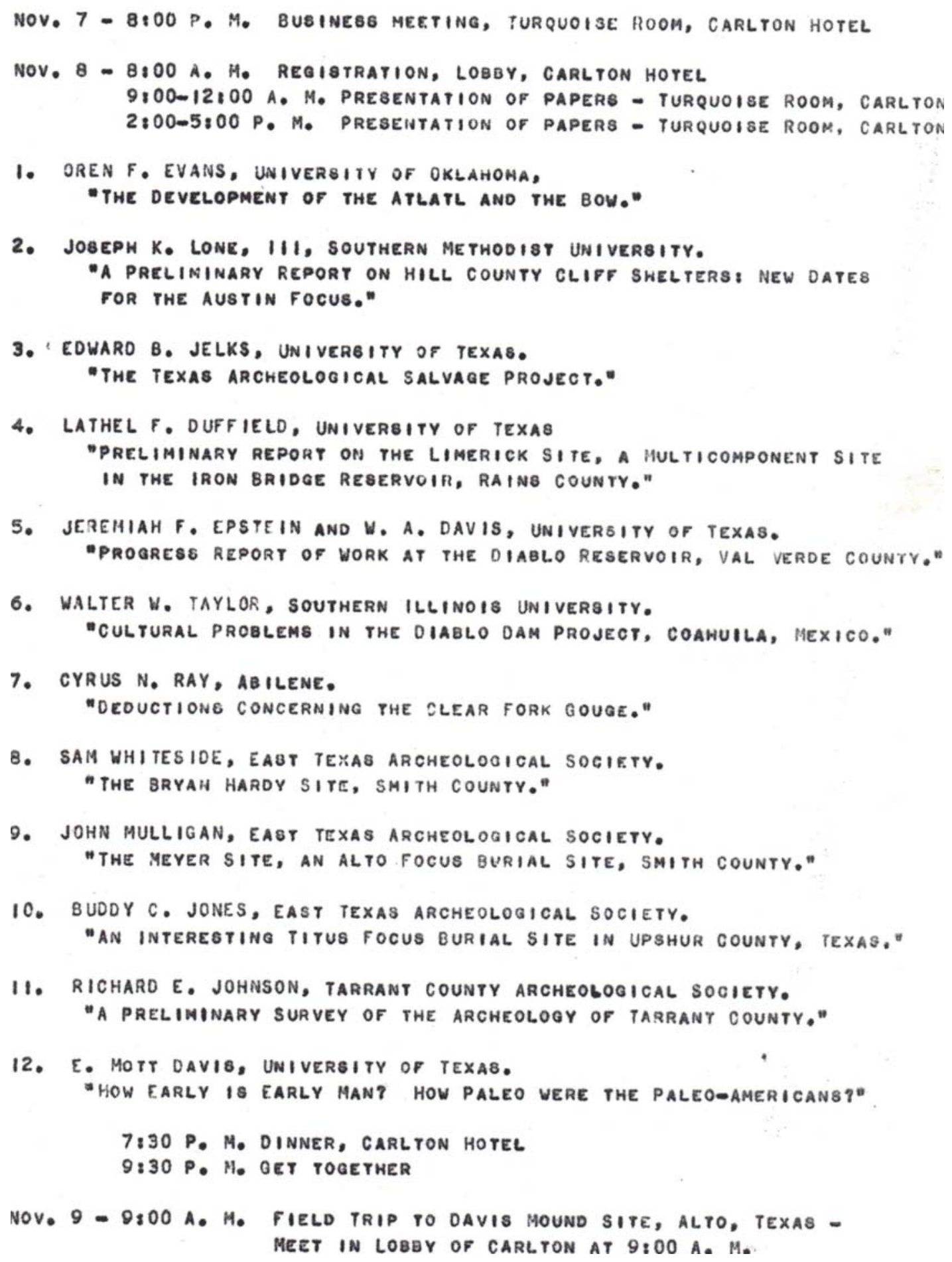




\title{
APPENDIX 15, NOVEMBER 1959 THANK YOU NOTE FROM TAS REGARDING THE 1958 TAS ANNUAL MEETING IN TYLER, TEXAS
}

\author{
THE TEXAS ARCHEOLOGICAL SOCIETY
}

WITTE MUSEUM

BRACKENRIDGE PARK

SAN ANTONIO 9, TEXAS

Vr. Douglas Proctor

1920 Robertson St.

Tyler, Texas

Dear Doug:

On behalf of the Texas Archaeological Society I wish to extend to the East Texas Archaeological Society a vote of thanks and a hearty congratulations on a fine meeting. The turn-out was excellent, the accomodations pleasant and convenient, and everything ran smoothly. We could ask for nothing more.

Since you left a little early you may not be aware that you were elected a Trustee of the Society. Also I did not get to check with you on the regional societf's expenses for the convention. The Society will gladly help out. Let me know on this score.

I would appreciate your turning this letter over to the East Texas Society. Thank you all for a fine time.

\section{Most Sincerely, Mardeth}

Mardith K. Schuetz Secretarv-Treasurer 
APPENDIX 16, APRIL 1, 1959 LETTER FROM E. MOTT DAVIS

Dear Sam,

$$
\text { Austin, } 4 / 1 / 59
$$

Congratulations on Vol. 1 No. 1 of Ancient NewS; I look forward to subsequent issues. I'll mention it in our forthcoming Texas Archeology.

From what you have to say, the Jamestown Nound site looks more and more interesting. Do you suppose the site might be stratified? Keep us informed.

$$
\text { Best to your family, as well as yourself. }
$$

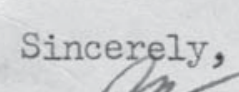

E.M.D. 


\section{APPENDIX 17, VOL. 1, NO. 2 OF THE ETAS NEWSLETTER, JULY 1959}

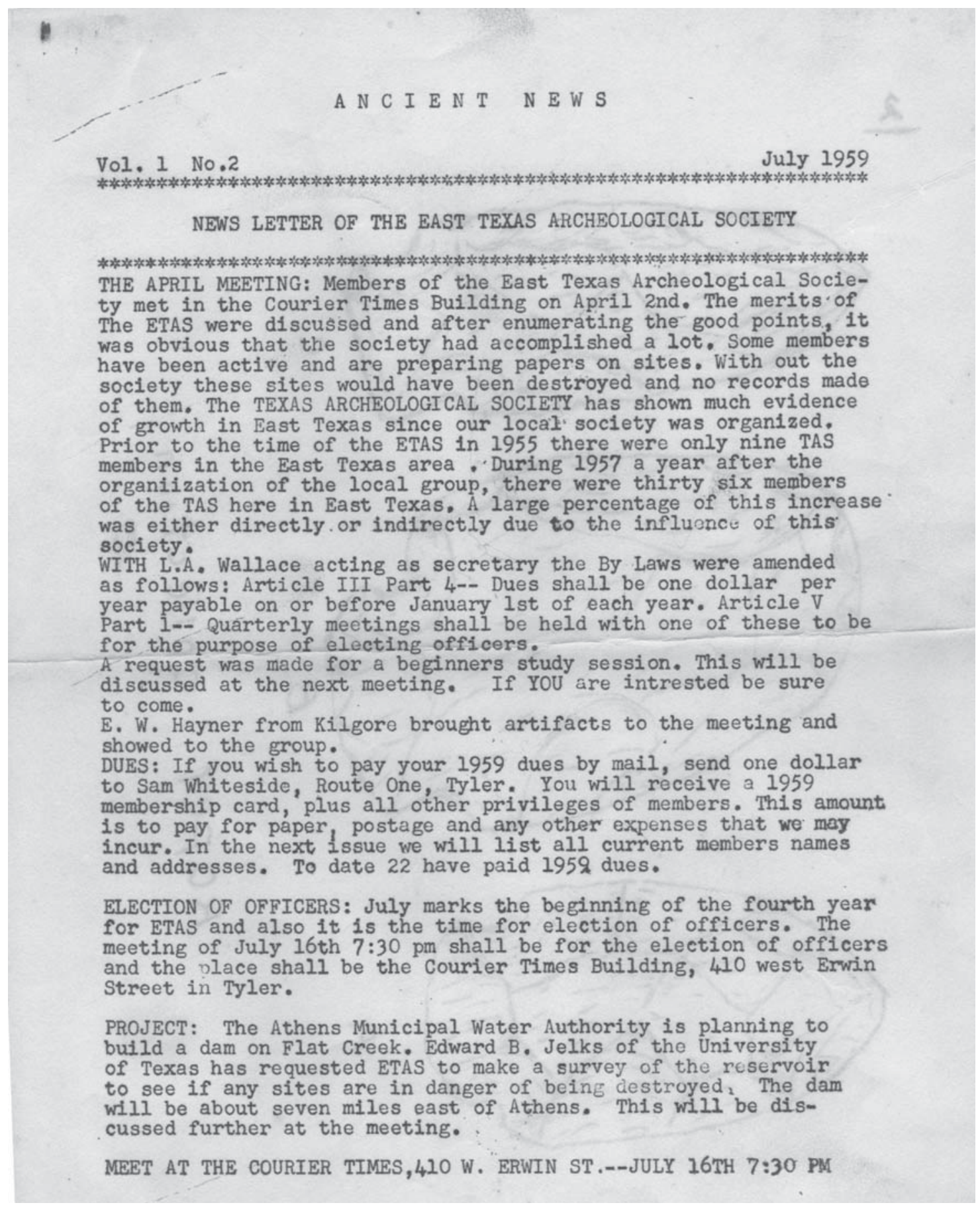




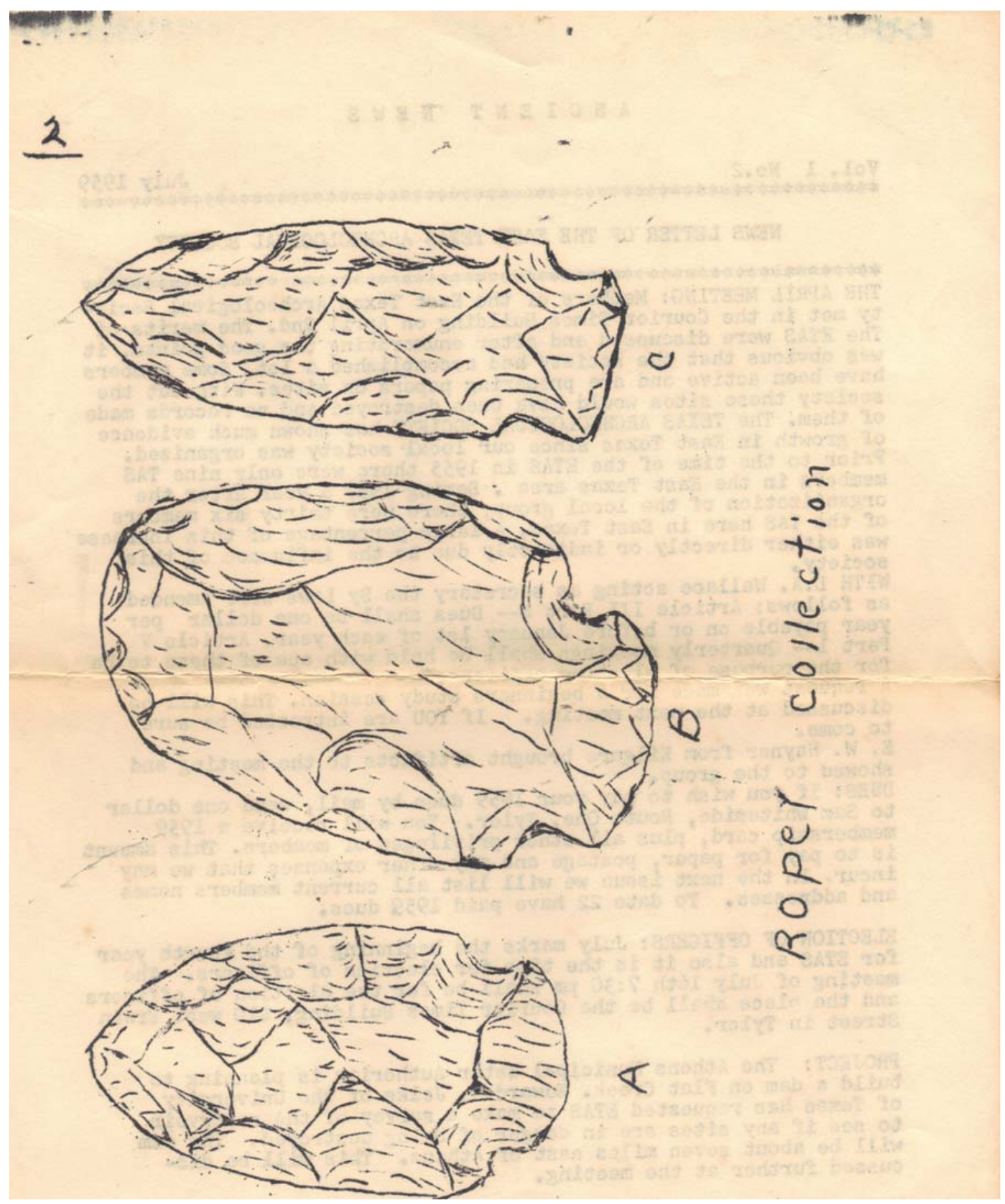




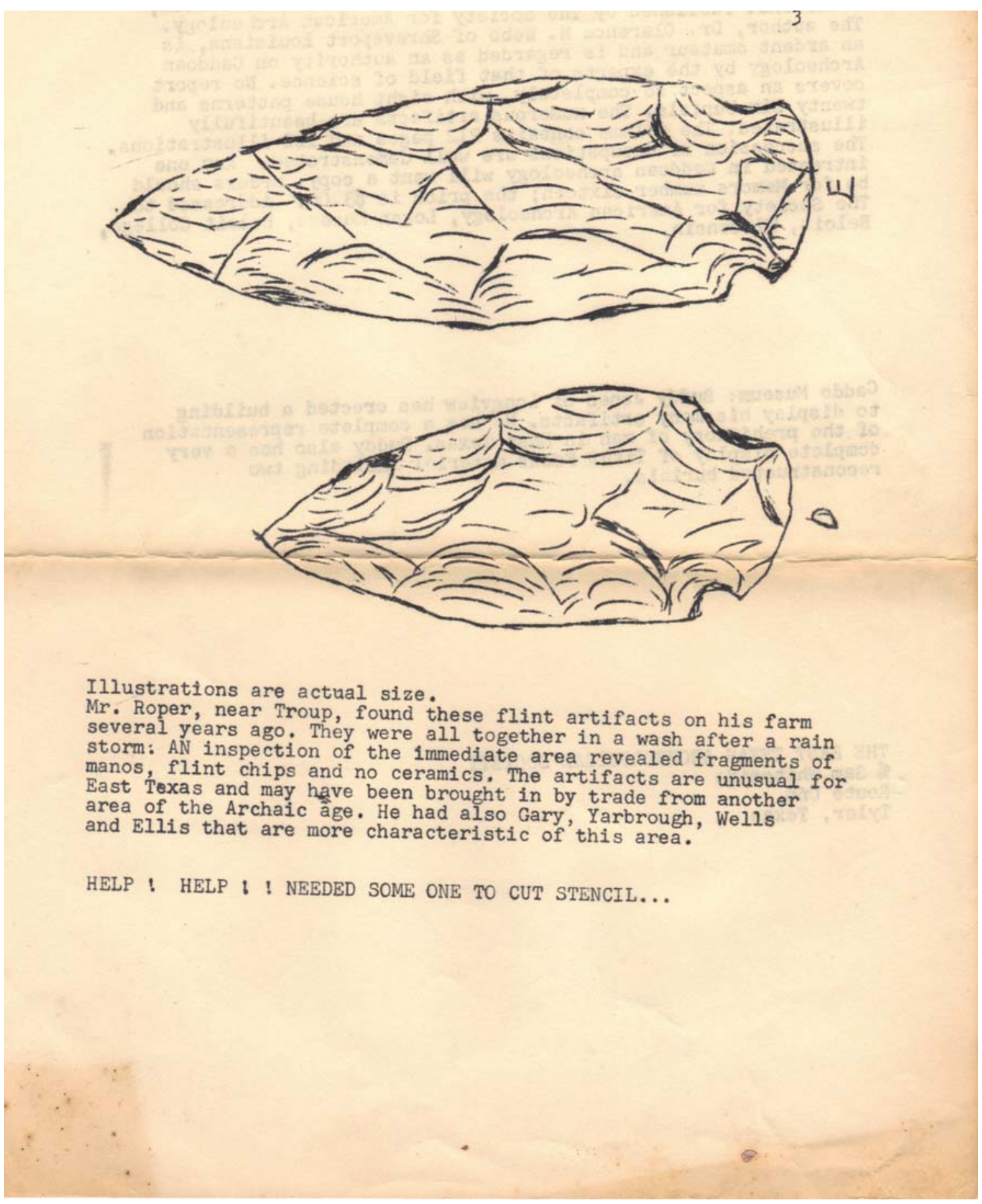


THE BELCHER MOUND A Stratified Caddoan Site in Caddo Parlsh, The author. Published by. The Society for American Archeology. an ardent amateur and is $\mathrm{H}$. Webb of Shrevejort Eouisiana, is Archeology by the experts of covers an aspect so.completely, with twenty six burials. The numer, with eight house patterns and illustrated. The volume contains artifacts are beautifully The succession of occupations 212 pages and 142 illustrations. intrested in Caddoan archeology will well demonstrated. Any one be for Memors number sixteen; will want a copy. Orders should The Society for American Arch; the price is $\$ 3.00$. Addressed to Beloit, Wisconsin.

Caddo Museum: Buddy Jones of Longview has erected a building of the prehistory of man in complete display of Titus Focus material Buddy also has a very reconstructed burials.

THE EAST TEXAS ARCHEOIOGICAL SOCIETY

$\%$ Sam Whiteside

Route One

Tyler. Texas 


\title{
APPENDIX 18, JUNE 26, 1959 LETTER FROM EDWARD B. JELKS
}

\author{
THE UNIVERSITY OF TEXAS \\ AUSTIN 12
}

DEPARTMENT OF ANTHROPOLOGY

June 26, 1959

Wr. Sam Whitesides

Route 1

Tyler, Texas

Dear Sam:

It has come to my attention that the Athens liunicipal Water Authority is planning to construct a small reservoir on Flat Creek east of Athens in the near future. I have written to Mr. J. P. Pickens, President of the Authority and he has sent me a map of the reservoir which I am enclosing with this letter. He did not indicate what the construction schedule is.

There could well be some important sites which will be damaged or destroyed by the Flat Creek project, and consequently, we would like to make a survey of the reservoir area. However, there is so much other work to be done in the coming year in Texas that I thought I would write to see if the East Texas Archeological Society would be interested in checking out the Flat Creek area for us. If you have society members who would be interestec in this project, it would also be helpful if they could prepare a brief report of the results of the survey.

Please let me know if your society is willing to undertake this projec If so, I will send a supply of site survey forms, etc., for your use.

With best regards.

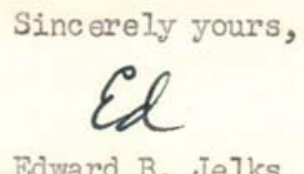

EBJ $:$ Ig

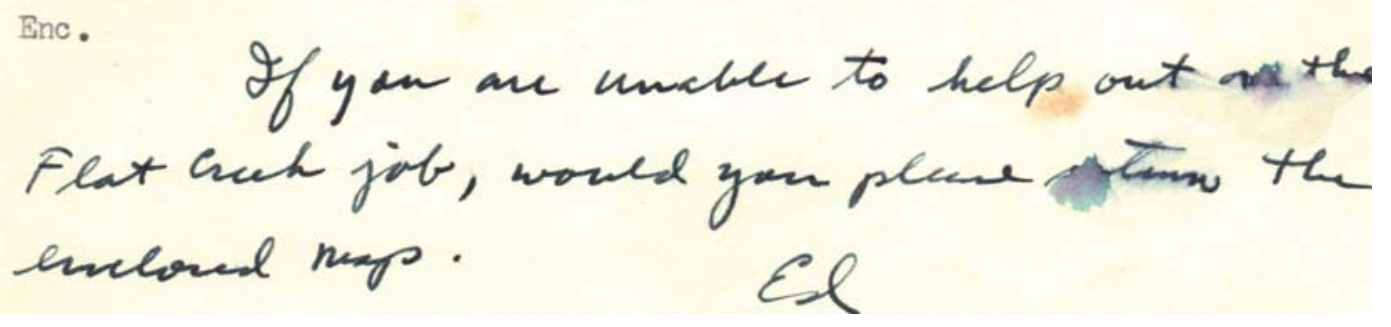




\title{
APPENDIX 19, JULY 15, 1959 LETTER FROM EDWARD B. JELKS
}

\author{
THE UNIVERSITY OF TEXAS \\ AUSTIN 12
}

DEPARTMENT OF ANTHROPOLOGY

July 15, 1959

Mr. Sam Whitesides

Rt. 1

Tyler, Texas

Dear Sam:

I was pleased to receive your letter of July 2 in which you say that there are enough interested society members at Tyler and Athens to make a prelininary survey of the Flat Creek Reservoir. It would be a big help to us if you would sort of take charge of this project and see that the reservoir area is covered as well as possible. We will be working at Iron Bridge this fall, probably in October or November, and I will plan to make an inspection trip to Flat Creek while we are over that way. Keep me informed as to the progress of the survey. If you need any site survey forms or other supplies, please let me know and I will send them to you.

Thank you for reporting that a skull has been dug up on Hooker Creek. We had already received a report about this from the Sabine River Authority, and we have the name of the boy who found the skull. The clearing of timber adjoining the Pearson Site has just been completed and Duffy is up there now checking the cleared area to see if any sites have been exposed. He will check on the burial while he is there.

With best regards.

Sincerely yours,

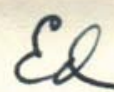

Edward B. Jelks

EBJ : fg 


\title{
APPENDIX 20, AUGUST 26, 1959 LETTER FROM EDWARD B. JELKS
}

\author{
THE UNIVERSITY OF TEXAS \\ AUSTIN 12
}

DEPARTMENT OF ANTHROPOLOGY

August 26, 1959

Mr. Sam Whiteside

Route 1

Tyler, Texas

Dear Sam:

Thank you for your letter of August 24. I am sorry to hear thaj you have been ill, and I trust you are all right now.

We have just completed a two-week dig at Whitney and plan to start work at Canyon Reservoir next week. We dug a small rockshelter at Whitney which produced a good deal of stuff from the Central Texas Aspect. We are scheduled to tackle the Pearson Site at Iron Bridge about the middle of October, and will try to test one of the sites at Cooper Reservoir just north of there while we are out. I will plan to spend a few days at Flat Creek while we are at Iron Bridge, probably about the end of October. I will visit any sites you have located at that time, and if you have not been able to cover the whole reservoir area, I will finish up the surbey. The help you are giving us is greatly appreciated.

I will let you know when we get started at Pearson, and I hope you will have time to visit the dig.

With best regards.

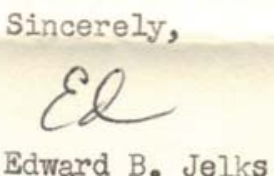

